\title{
Atmospheric mixing ratios of methyl ethyl ketone (2-butanone) in tropical, boreal, temperate and marine environments
}

\author{
A. M. Yáñez-Serrano ${ }^{1,2, a}$, A. C. Nölscher ${ }^{1, b}$, E. Bourtsoukidis ${ }^{1}$, B. Derstroff ${ }^{1}$, N. Zannoni ${ }^{3}$, V. Gros ${ }^{3}$, M. Lanza ${ }^{4}$, \\ J. Brito ${ }^{5}$, S. M. Noe ${ }^{6}$, E. House ${ }^{7}$, C. N. Hewitt ${ }^{7}$, B. Langford ${ }^{8}$, E. Nemitz ${ }^{8}$, T. Behrendt ${ }^{1, c}$, J. Williams ${ }^{1}$, P. Artaxo ${ }^{5}$, \\ M. O. Andreae ${ }^{1,9}$, and J. Kesselmeier ${ }^{1}$ \\ ${ }^{1}$ Biogeochemistry and Air Chemistry Departments, Max Planck Institute for Chemistry, P.O. Box 3060, \\ 55020 Mainz, Germany \\ ${ }^{2}$ Instituto Nacional de Pesquisas da Amazônia (INPA), Av. André Araújo 2936, Manaus-AM, 69083-000, Brazil \\ ${ }^{3}$ Laboratoire des Sciences du Climat et de l'Environnement, LSCE/IPSL, CEA-CNRS-UVSQ, Université Paris-Saclay, \\ 91191 Gif-sur-Yvette, France \\ ${ }^{4}$ IONICON Analytik GmbH, Eduard-Bodem-Gasse 3, 6020, Innsbruck, Austria \\ ${ }^{5}$ Instituto de Física, Universidade de São Paulo (USP), Rua do Matão, Travessa R, 187, CEP 05508-900, São Paulo-SP, Brazil \\ ${ }^{6}$ Institute of Agricultural and Environmental Sciences, Estonian University of Life Sciences, Kreutzwaldi 1, \\ 51014 Tartu, Estonia \\ ${ }^{7}$ Lancaster Environment Centre, Lancaster University, Lancaster, LA1 4YQ, UK \\ ${ }^{8}$ Centre for Ecology \& Hydrology, Penicuik, EH26 0QB, UK \\ ${ }^{9}$ Scripps Institution of Oceanography, University of California San Diego, La Jolla, CA 92037, USA \\ a now at: Department of Ecosystem Physiology, University of Freiburg, 79085 Freiburg, Germany \\ ${ }^{b}$ now at: Division of Geological and Planetary Sciences, California Institute of Technology, Pasadena, CA 91125, USA \\ ${ }^{c}$ now at: Department of Biogeochemical Processes, Max Planck Institute for Biogeochemistry, Hans-Knöll-Str. 10, \\ 07745 Jena, Germany
}

Correspondence to: A. M. Yáñez-Serrano (a.yanezserrano@mpic.de)

Received: 12 April 2016 - Published in Atmos. Chem. Phys. Discuss.: 25 April 2016

Revised: 10 August 2016 - Accepted: 17 August 2016 - Published: 6 September 2016

\begin{abstract}
Methyl ethyl ketone (MEK) enters the atmosphere following direct emission from vegetation and anthropogenic activities, as well as being produced by the gas-phase oxidation of volatile organic compounds (VOCs) such as $n$ butane. This study presents the first overview of ambient MEK measurements at six different locations, characteristic of forested, urban and marine environments. In order to understand better the occurrence and behaviour of MEK in the atmosphere, we analyse diel cycles of MEK mixing ratios, vertical profiles, ecosystem flux data, and HYSPLIT back trajectories, and compare with co-measured VOCs. MEK measurements were primarily conducted with protontransfer-reaction mass spectrometer (PTR-MS) instruments. Results from the sites under biogenic influence demonstrate that vegetation is an important source of MEK. The diel cycle of MEK follows that of ambient temperature and the
\end{abstract}

forest structure plays an important role in air mixing. At such sites, a high correlation of MEK with acetone was observed (e.g. $r^{2}=0.96$ for the SMEAR Estonia site in a remote hemiboreal forest in Tartumaa, Estonia, and $r^{2}=0.89$ at the ATTO pristine tropical rainforest site in central Amazonia). Under polluted conditions, we observed strongly enhanced MEK mixing ratios. Overall, the MEK mixing ratios and flux data presented here indicate that both biogenic and anthropogenic sources contribute to its occurrence in the global atmosphere. 


\section{Introduction}

Methyl ethyl ketone $\left(\mathrm{C}_{4} \mathrm{H}_{8} \mathrm{O}\right.$; MEK, also known as 2butanone, butanone, methyl acetone, butan-2-one, methylpropanone and ethyl methyl ketone) is an oxygenated volatile organic compound (OVOC). Its occurrence in the atmosphere has been reported over a wide range of environments (Cecinato et al., 2002; Hellén et al., 2004; Ho et al., 2002; Kim et al., 2015; McKinney et al., 2011; Singh et al., 2004) with typical mixing ratios of 0.03-4 ppb (Ciccioli and Mannozzi, 2007; Kim et al., 2015). Although often being measured alongside other volatile organic compounds (VOCs), atmospheric MEK has received little attention to date. The photochemistry of acetone may serve as an example of how ketones affect the composition and chemistry of the atmosphere by delivering free radicals to the upper troposphere (Colomb et al., 2006; Finlayson-Pitts and Pitts, 2000; McKeen et al., 1997) and thus increasing the ozone formation potential and altering the oxides of nitrogen $\left(\mathrm{NO}_{x}\right)$ regime (Ciccioli and Mannozzi, 2007; Folkins et al., 1998; Prather and Jacob, 1997). This understanding may be transferred to MEK, as this molecule is structurally similar to acetone, with a comparable absorption spectrum (Martinez et al., 1992). Several studies report that the mixing ratio of MEK in the free troposphere is roughly one-quarter of that of acetone (Moore et al., 2012; Singh et al., 2004). However, MEK is about an order of magnitude more reactive than acetone with respect to the hydroxyl radical $(\mathrm{OH})$ (Atkinson, 2000), which makes it a compound of interest in ongoing discussions about the inability to fully account for the reactivity of $\mathrm{OH}$ (Nölscher et al., 2016).

There are several known but poorly characterised sources of MEK to the atmosphere. Terrestrial vegetation (BrachoNunez et al., 2013; Brilli et al., 2014; Davison et al., 2008; De Gouw et al., 1999; Isidorov et al., 1985; Jardine et al., 2010; Kirstine et al., 1998; König et al., 1995; McKinney et al., 2011; Ruuskanen et al., 2011; Song and Ryu, 2013; Steeghs et al., 2004; Wilkins, 1996; Yáñez-Serrano et al., 2015), fungi (Wheatley et al., 1997) and bacteria (Song and Ryu, 2013; Wilkins, 1996) are known to emit MEK. It is also emitted directly by several anthropogenic sources, including anthropogenic biomass burning (Andreae and Merlet, 2001), solvent evaporation (Kim et al., 2015; Legreid et al., 2007) and vehicle exhaust (Bon et al., 2011; Brito et al., 2015; Liu et al., 2015; Verschueren, 1983). In addition, MEK can be formed via the atmospheric oxidation of other compounds (de Gouw et al., 2003; Jenkin et al., 1997; Neier and Strehlke, 2002; Sommariva et al., 2011).

Looking in more detail at biogenic sources, MEK emissions have been observed from different types of vegetation, including forest canopies (Brilli et al., 2014; Jordan et al., 2009b; Yáñez-Serrano et al., 2015), pasture (Davison et al., 2008; De Gouw et al., 1999; Kirstine et al., 1998) and clover (De Gouw et al., 1999; Kirstine et al., 1998). The MEK production and release mechanisms are manifold but poorly un- derstood. Studies show higher MEK emissions after cutting and drying of leaves than under no-stress conditions (Davison et al., 2008; De Gouw et al., 1999). Due to the water solubility of MEK in leaves and on surfaces (Sander, 2015), Jardine et al. (2010) suggested MEK emissions to be dependent on evaporation from storage pools in leaves. It has been suggested that MEK takes part in tri-trophic signalling following herbivore attack (Jardine et al., 2010; Song and Ryu, 2013). The roots of plants have also been found to release MEK in root-aphid interactions (Steeghs et al., 2004). Decaying plant tissue may also act as a source of MEK to the atmosphere (Warneke et al., 1999). Furthermore, some studies indicate the importance of MEK emissions by microbes, such as Brevibacterium linens, Bacillus spp. and thermophilic Gram-positive actinomycetes bacteria (Song and Ryu, 2013; Wilkins, 1996), and fungi such as Trichoderma spp. (Wheatley et al., 1997).

MEK not only enters the atmosphere via direct emissions but also results from the atmospheric photooxidation of VOCs such as $n$-butane, 2-butanol, 3-methyl pentane and 2-methyl-1-butene (de Gouw et al., 2003; Jenkin et al., 1997; Neier and Strehlke, 2002; Sommariva et al., 2011). Although butane in the atmosphere comes predominantly from anthropogenic sources (Kesselmeier and Staudt, 1999), some studies have reported emission of $n$-butane from vegetation (Donoso et al., 1996; Greenberg and Zimmerman, 1984; Hellén et al., 2006; König et al., 1995; Zimmerman et al., 1988). The MEK yield from $n$-butane oxidation is $\sim 80 \%$ (Singh et al., 2004). It is important to note that no mechanistic pathways have been found for atmospheric MEK production from the dominant biogenic VOCs isoprene, $\alpha$-pinene and $\beta$ pinene, as well as from methyl butenol oxidation (Rollins et al., 2009; Singh et al., 2004).

In the atmosphere MEK reacts mainly with $\mathrm{OH}\left(k_{\mathrm{OH}}=\right.$ $1.15 \times 10^{-12} \mathrm{~cm}^{3} \mathrm{~s}^{-1}$ ) (Chew and Atkinson, 1996), while reactions with $\mathrm{O}_{3}$ and $\mathrm{NO}_{3}$ are very slow during the day and hence negligible (Atkinson and Arey, 2003). MEK has a lifetime of 5.4 days at an $\mathrm{OH}$ concentration of $1.6 \times$ $10^{6}$ radicals $\mathrm{cm}^{-3}$, whereas isoprene and acetone have lifetimes of $8.2 \mathrm{~h}$ and 38 days, respectively, under the same conditions (Grant et al., 2008). The atmospheric degradation of MEK leads to acetaldehyde and formaldehyde formation. In the presence of $\mathrm{NO}_{x}$, MEK can lead to peroxyacetyl nitrate (PAN) and ozone formation (Grosjean et al., 2002; Pinho et al., 2005). In the upper troposphere, MEK photolyses and regenerates OH (Atkinson, 2000; Baeza Romero et al., 2005; De Gouw et al., 1999), as does acetone, potentially increasing ozone formation.

Anthropogenic biomass burning leads to significant MEK emissions of about $2 \mathrm{Tg} \mathrm{a}^{-1}$ globally (Andreae and Merlet, 2001, and unpublished updates; Schauer et al., 2001). Furthermore, about $9 \mathrm{Tg} \mathrm{a}^{-1}$ of other $\mathrm{C}_{4}$ compounds is emitted by biomass burning, which may act as MEK precursors. Another strong source of MEK is biofuel and charcoal combustion, with emissions of $\sim 830 \mathrm{mg} \mathrm{kg}^{-1}$ of dry 
biomass (compared to an emission rate of $\sim 260 \mathrm{mg} \mathrm{kg}^{-1}$ of dry mass for biomass burning of savannah and grassland vegetation types; Andreae and Merlet, 2001). Despite the fact that biomass burning emission rates have been fairly well characterised, vehicular emissions, food cooking, industrial activities, cigarette smoke and other anthropogenic sources have not been characterised. Even though MEK is present in urban atmospheres, there are no observations of MEK emissions from vehicles. Most of the urban MEK is released to the atmosphere via evaporation from chemical plants and industrial and household applications, as it is widely used as a solvent (e.g. in glues and as a paint thinner). It has a low toxicity and is not carcinogenic (National Center for Biotechnology, 2015). As its manufacturing has been increasing in the last 10 years, global atmospheric mixing ratios have probably increased as well.

Here we report recent findings on MEK from six different sites, including biogenic- and anthropogenic-dominated environments, in order to understand MEK sources in different environments. Our large dataset allows a closer view of this important, almost ubiquitous species in Earth's atmosphere.

\section{Sites and methodology}

The field sites compared in our study cover areas from pristine to remote anthropogenically influenced tropical forests, as well as boreal and Mediterranean regions. Measurements were performed using proton-transfer-reaction mass spectrometry (PTR-MS) and partly complemented by gas chromatography-flame ionisation detection (GC-FID) and gas chromatography-mass spectrometry (GC-MS) analytical techniques (Fig. 1, Table 1).

Online MEK measurements were performed with quadrupole PTR-MSs (Ionicon Analytic GmbH, Austria; Lindinger et al., 1998) at all sites except for CYPHEX, where a proton transfer reaction time-of-flight mass spectrometer (PTR-ToF-MS, Ionicon Analytic GmbH, Austria; Jordan et al., 2009a) was used. The PTR-MSs were operated at standard conditions $(2.2 \mathrm{mbar}$ drift pressure, $600 \mathrm{~V}$ drift voltage, $142 \mathrm{Td}$ for ATTO and SMEAR Estonia; $2.0 \mathrm{mbar}$ drift pressure, $550 \mathrm{~V}$ drift voltage, $129 \mathrm{Td}$, for TT34; $2.2 \mathrm{mbar}$ drift pressure, $600 \mathrm{~V}$ drift voltage, $135 \mathrm{Td}$ for $\mathrm{O}_{3} \mathrm{HP} ; 2.2 \mathrm{mbar}$ drift pressure, $560 \mathrm{~V}$ drift voltage, $132 \mathrm{Td}$ for $\mathrm{T} 2$; and $2.2 \mathrm{mbar}$ drift pressure, $600 \mathrm{~V}$ drift voltage, 137 Td for CYPHEX).

Periodic background measurements and weekly humid calibrations were performed at all sites. Gravimetrically prepared multicomponent standards were obtained from Apel \& Riemer, USA, for ATTO, TT34, T2 and CYPHEX and from Ionicon Analytik $\mathrm{GmbH}$, Austria, for $\mathrm{O}_{3} \mathrm{HP}$ and SMEAR Estonia.

\subsection{The Amazon Tall Tower Observatory, ATTO: pristine tropical rainforest (Amazon, Brazil)}

The Amazon Tall Tower Observatory (ATTO) site is located in central Amazonia, $150 \mathrm{~km}$ NE of Manaus, Brazil (Fig. 1), within a pristine primary tropical rainforest. The site is equipped with a tall tower $(325 \mathrm{~m})$ and two $80 \mathrm{~m}$ towers. One of them $\left(02^{\circ} 08^{\prime} 38.8^{\prime \prime} \mathrm{S}, 58^{\circ} 59^{\prime} 59.5^{\prime \prime} \mathrm{W}\right)$ is an $80 \mathrm{~m}$ walk-up tower, where the trace gas measurements take place. It is surrounded by a forest with a canopy height of approximately $35 \mathrm{~m}$ and with at least 417 different tree species among 7293 screened trees of $\geq 10 \mathrm{~cm}$ diameter at breast height (DBH) in the twelve 1 ha inventoried plots (Andreae et al., 2015). The climate of this site is typical for tropical rainforests with a drier season (July-October) and a wet season (December-April; Nobre et al., 2009).

Measurements for this study took place 18 February15 March 2014. They were carried out at seven different heights $(0.05,0.5,4,24,53$ and $79 \mathrm{~m})$ with the PTR-MS switching sequentially between each height in 2 min intervals. The inlet lines were made of PTFE ( $9.5 \mathrm{~mm}$ OD), insulated and heated to $50^{\circ} \mathrm{C}$, and had PTFE particle inlet filters. More information about the gradient system and PTRMS operation at ATTO can be found elsewhere (Nölscher et al., 2016; Yáñez-Serrano et al., 2015). The limit of detection (LOD) and uncertainty in the PTR-MS were $0.05 \mathrm{ppb}$ and $34 \%$, respectively.

Additionally, ambient samples for offline measurements with GC-FID were taken on 11 March 2014 from 08:30 to 11:00 LT. They were collected at $24 \mathrm{~m}$ using a GSA SG10-2 personal sampler pump and adsorber tubes $(130 \mathrm{mg}$ of Carbograph $1\left(90 \mathrm{~m}^{2} \mathrm{~g}^{-1}\right)$ followed by $130 \mathrm{mg}$ of Carbograph $\left.5\left(560 \mathrm{~m}^{2} \mathrm{~g}^{-1}\right)\right)$. The size of the Carbograph particles was in the range of 20-40 mesh. Carbograph 1 and 5 were provided by Lara s.r.l. (Rome, Italy). Samples were collected for $20 \mathrm{~min}$ with a flow of $167 \mathrm{~mL} \mathrm{~min}^{-1}$ passing about $3.3 \mathrm{~L}$ of ambient air through the adsorbent. Cartridges were transported to the laboratory for analysis by a Perkin Elmer Autosystem XL GC-FID. These samples generally matched the results of the PTR-MS. For details on sampling see Kesselmeier et al. (2002).

\subsection{TT34: remote tropical rainforest (Amazon, Brazil)}

The ZF2 site is located in the Reserva Biologica do Cuieiras in central Amazonia, $60 \mathrm{~km} \mathrm{NNW}$ of Manaus $\left(2^{\circ} 35^{\prime} 39.4^{\prime \prime} \mathrm{S}\right.$, $60^{\circ} 12^{\prime} 33.4^{\prime \prime} \mathrm{W}$ ) within a remote primary tropical rainforest (Fig. 1). The site is equipped with two towers, TT34 and the K34. The TT34 triangular tower is $40 \mathrm{~m}$ high and embedded within the forest with a canopy height of approximately $30 \mathrm{~m}$. The biodiversity of this site is also high and the climate is very similar to that at the ATTO site. More information about the site can be found elsewhere (Karl et al., 2009; Martin et al., 2010). 
Table 1. Measurement sites, site environment, sampling dates, methods used and sampling heights.

\begin{tabular}{|c|c|c|c|c|c|c|}
\hline Site & Characteristics & Canopy height & Time of sampling & Technique & $\begin{array}{l}\text { Type of } \\
\text { measurement }\end{array}$ & $\begin{array}{l}\text { Measurement } \\
\text { heights }\end{array}$ \\
\hline $\begin{array}{l}\text { ATTO } \\
\text { (Brazil) }\end{array}$ & $\begin{array}{l}\text { Pristine tropical } \\
\text { rainforest }\end{array}$ & $35 \mathrm{~m}$ dense veg. & Feb/Mar 2014 & $\begin{array}{l}\text { PTR-MS } \\
\text { GC-FID (samples for of- } \\
\text { fline analysis, collected } \\
\text { volume }=3.34 \mathrm{~L} \text { ) }\end{array}$ & Ambient & $\begin{array}{l}0.05,0.5,4,24, \\
38,53,79 \mathrm{~m} \\
24 \mathrm{~m}\end{array}$ \\
\hline $\begin{array}{l}\text { TT34 } \\
\text { (Brazil) }\end{array}$ & $\begin{array}{l}\text { Remote tropical } \\
\text { rainforest }\end{array}$ & $30 \mathrm{~m}$ dense veg. & Sep 2013-Jul 2014 & PTR-MS & $\begin{array}{l}\text { Ambient, } \\
\text { including } \\
\text { canopy-scale } \\
\text { fluxes }\end{array}$ & $41 \mathrm{~m}$ \\
\hline $\begin{array}{l}\text { SMEAR } \\
\text { (Estonia) }\end{array}$ & $\begin{array}{l}\text { Remote hemibo- } \\
\text { real forest }\end{array}$ & $\begin{array}{l}16-20 \mathrm{~m} \text { dense } \\
\text { veg. }\end{array}$ & $\begin{array}{l}\text { Jun, Jul, Oct } 2012 \\
\text { Oct } 2012\end{array}$ & $\begin{array}{l}\text { GC-MS (samples for of- } \\
\text { fline analysis, collected } \\
\text { volume }=6 \mathrm{~L} \text { ) } \\
\text { PTR-MS }\end{array}$ & $\begin{array}{l}\text { Ambient, plant, } \\
\text { soil enclosure } \\
\text { Ambient, plant } \\
\text { enclosure }\end{array}$ & $\begin{array}{l}2,20 \mathrm{~m} \\
16 \mathrm{~m}\end{array}$ \\
\hline $\begin{array}{l}\mathrm{O}_{3} \mathrm{HP} \\
\text { (France) }\end{array}$ & $\begin{array}{l}\text { Rural temperate } \\
\text { forest }\end{array}$ & $5 \mathrm{~m}$ sparse veg. & May-Jun 2014 & PTR-MS & Ambient & $2 \mathrm{~m}$ \\
\hline $\begin{array}{l}\mathrm{T} 2 \\
\text { (Brazil) }\end{array}$ & $\begin{array}{l}\text { Mixed urban- } \\
\text { and rainforest- } \\
\text { influenced envi- } \\
\text { ronment }\end{array}$ & $\begin{array}{l}\text { Influence from } \\
\text { veg. nearby }\end{array}$ & $\begin{array}{l}\text { Feb-Apr } 2014 \\
\text { Jul-Oct } 2014\end{array}$ & PTR-MS & Ambient & $14 \mathrm{~m}$ \\
\hline $\begin{array}{l}\text { CYPHEX } \\
\text { (Cyprus) }\end{array}$ & $\begin{array}{l}\text { Mixed marine, } \\
\text { rural environment } \\
\text { influenced by } \\
\text { aged air masses }\end{array}$ & $\begin{array}{l}\text { None, on top of } \\
\text { a hill }\end{array}$ & Jul-Aug 2014 & PTR-TOF-MS & Ambient & $8 \mathrm{~m}$ \\
\hline
\end{tabular}

Measurements for this study were made from 1 September 2013 to 20 July 2014 at $41 \mathrm{~m}$, at a fast rate $(0.5 \mathrm{~Hz})$ for virtual disjunct eddy covariance (vDEC) flux derivations techniques (Karl et al., 2002; Langford et al., 2009; Rinne et al., 2002). The high-resolution data were further averaged to give $30 \mathrm{~min}$ concentration and flux data. Wind vector data were obtained with a sonic anemometer (Gill R3, USA) mounted at the top of the tower close to the PTR-MS inlet. The PTR-MS inlet line was made of PFA (12.7 mm OD) (PFA-T8-062-100, Swagelok) and was insulated and heated to $40^{\circ} \mathrm{C}$ inside the air-conditioned cabin. The LOD and uncertainty averaged $30 \mathrm{~min}$ concentrations measurements were $0.18 \mathrm{ppb}$ and $6 \%$, respectively.

\subsection{Station for Measuring Ecosystem-Atmosphere Relations, SMEAR Estonia: remote hemiboreal forest (Tartumaa, Estonia)}

The Station for Measuring Ecosystem-Atmosphere Relations (SMEAR Estonia) site is located in the Järvselja Experimental Forestry station in Tartumaa, SE Estonia $\left(58^{\circ} 16^{\prime} \mathrm{N}\right.$ $27^{\circ} 16^{\prime} \mathrm{E}$ ), within a remote hemiboreal zone, far from major anthropogenic disturbances (Noe et al., 2011; Fig. 1). The site is equipped with a tower of $24 \mathrm{~m}$ height. The surrounding canopy is about $16-20 \mathrm{~m}$ in height and the remote hemiboreal forest consists of a mixture of tree species, with Norway spruce (Picea abies) dominating. The climate is boreal with a growing season of 170-180 days. More information about the site can be found elsewhere (e.g. Bourtsoukidis et al., 2014a; Noe et al., 2011, 2016).

The measurements were made between 3 and 17 October 2012. Sampling was done using a dynamic, automated glass enclosure with measurement cycles of $36 \mathrm{~s}$. The inlet line $(9.5 \mathrm{~mm}$ OD) was made of glass and was insulated and heated to $70^{\circ} \mathrm{C}$. A dynamic exchange enclosure was used to measure emission rates from a Norway spruce branch located in the upper canopy at $16 \mathrm{~m}$. While the focus of this study was the quantification of emission rates of MEK from a Norway spruce tree, ambient mixing ratios were derived as well using the box model described in Bourtsoukidis et al. (2014b). The LOD and uncertainty of the PTR-MS were $0.04 \mathrm{ppb}$ and $28 \%$, respectively.

Furthermore, at SMEAR Estonia, offline measurements with a GC-MS were carried out for periods of 3 days each in June and July 2012, with samples taken every $4 \mathrm{~h}$ at two heights ( 2 and $20 \mathrm{~m}$ ). Samples for GC-MS analysis were also taken from cuvettes enclosing some common plant species at the site (Table 1). In addition, VOC emissions from soil litter were monitored monthly. The air samples were drawn into multi-bed stainless steel cartridges $(10.5 \mathrm{~cm}$ length, $3 \mathrm{~mm}$ inner diameter, Supelco, Bellefonte, PA, USA) filled with Carbotrap C 20/40 mesh (0.2 g), Carbopack C 40/60 mesh (0.1 g) and Carbotrap X 20-40 mesh (0.1 g) adsorbents (Supelco). Even though the site usually experiences low ozone mix- 


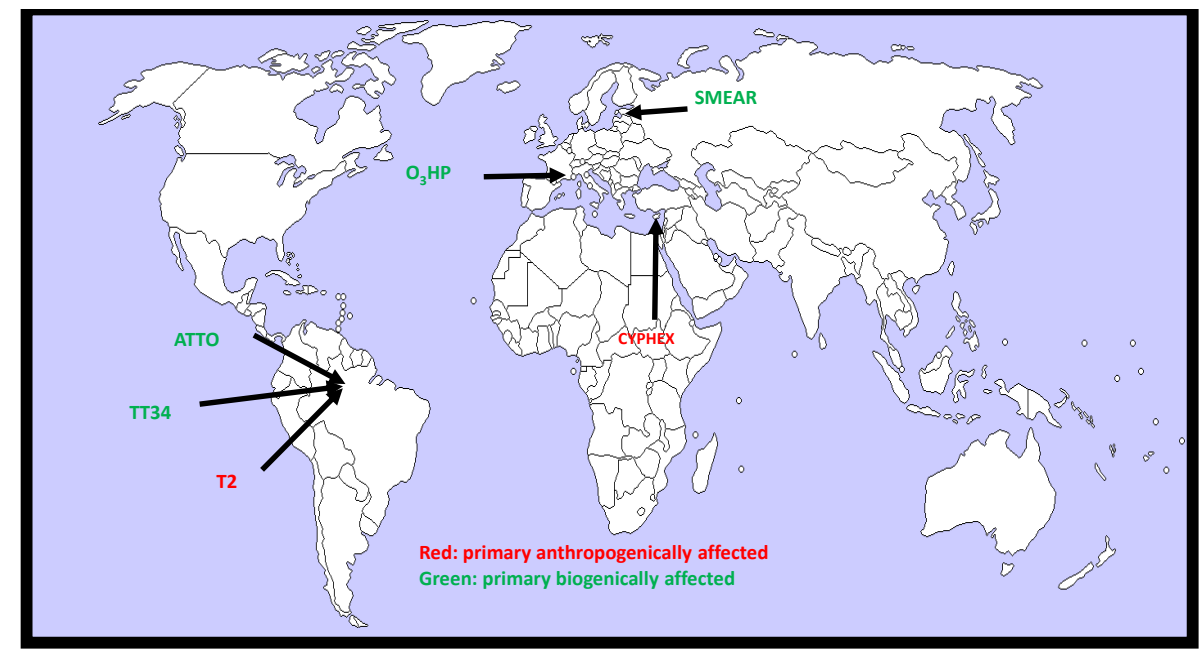

Figure 1. World map showing the location of the different sites. The names are colour-coded to show whether they have primarily biogenic influence (green) or a primarily anthropogenic influence (red). Source: outline world map, http://www.outline-world-map.com/ political-white-world-map-b6a, last access: 1 September 2016.

ing ratios of 10-30 ppb (Noe et al., 2012), a catalytic $\mathrm{Cu}(\mathrm{II})$ ozone scrubbing system (Sun et al., 2012) was applied. Three constant-flow air sample pumps (1003-SKC, SKC Inc., Huston, TX, USA) and one multisample constant-flow air sample pump (224-PCXR8, SKC Inc., Huston, TX, USA) allowed four samples to be collected at the same time. Each sample took 30 min with a flow of $200 \mathrm{~mL} \mathrm{~min}^{-1}$ concentrating $6 \mathrm{~L}$ of ambient air onto the adsorbent. More information can be found elsewhere (Noe et al., 2012).

\subsection{Observatoire de Haute Provence, $\mathrm{O}_{3} \mathrm{HP}$ : rural Mediterranean temperate forest (Provence, France)}

The oak observatory $\left(\mathrm{O}_{3} \mathrm{HP}\right.$, https://o3hp.obs-hp.fr) at the "Observatoire de Haute Provence" (OHP, http://www. obs-hp.fr/welcome.shtml) is located within a rural Mediterranean temperate forest in the French Mediterranean region, $60 \mathrm{~km}$ north of Marseille, the closest large city $\left(43^{\circ} 55^{\prime} 54.0^{\prime \prime} \mathrm{N}, 5^{\circ} 42^{\prime} 43.9^{\prime \prime} \mathrm{E}\right.$; Fig. 1). A $10 \mathrm{~m}$ mast was set up inside the oak forest with a canopy height of approximately $5 \mathrm{~m}$. The $\mathrm{O}_{3} \mathrm{HP}$ site is dominated by Quercus pubescens Willd. (75\% of trees) and Acer monspessulanum L. $(25 \%)$ forming a sparse canopy, while Cotinus coggygria Scop. and other grass species constitute the understorey canopy. The climate at the site is typical Mediterranean, with dry and hot summers and humid and cool winters. More information about the site can be found elsewhere (GenardZielinski et al., 2015; Kalogridis et al., 2014).

The measurements took place during 29 May12 June 2014 as part of the CANOPÉE project (Biosphereatmosphere exchange of organic compounds: impact of intra-canopy processes). Ambient measurements were carried out at $2 \mathrm{~m}$ (inside the canopy) on consecutive days in intervals of $5 \mathrm{~min}$. The $9.5 \mathrm{~mm}$ OD Teflon inlet lines were insulated and heated above ambient temperature and had no particle filter. The LOD and uncertainty of the PTR-MS were $0.11 \mathrm{ppb}$ and $20 \%$, respectively. In addition, light non-methane hydrocarbons (from ethane to hexane) were measured with a GC-FID (Chromatotec, Saint-Antoine, France) in line with the PTR-MS as described in Zannoni et al. (2016).

\subsection{T2: mixed urban- and rainforest-influenced environment (Amazon, Brazil)}

The T2 site is part of a set of experimental sites within the GoAmazon project to study the effect of the pollution plume from the city of Manaus on the otherwise pristine Amazonian atmosphere. The T2 site is located $8 \mathrm{~km}$ downwind, i.e. to the west, of Manaus ( $3^{\circ} 8^{\prime} 21.12^{\prime \prime} \mathrm{S}, 60^{\circ} 7^{\prime} 53.52^{\prime \prime} \mathrm{W}$; Fig. 1). Given its location, near Manaus and across the Rio Negro, air mass transport to the sampling site is strongly modulated by a river breeze, alternating between mostly biogenic conditions, resulting from the surrounding forest, and the city emissions. The climate is tropical and similar to that at the ATTO and ZF2 sites.

The measurements for this study took place between 15 February and 15 November 2014. They were carried out at $12 \mathrm{~m}$ above the laboratory container with $30 \mathrm{~min}$ cycles. The inlet line was made of insulated Teflon $(9.5 \mathrm{~mm} \mathrm{OD})$ without a PTFE particle filter. The LOD and uncertainty of the PTR-MS were $0.02 \mathrm{ppb}$ and $\sim 30 \%$, respectively. 


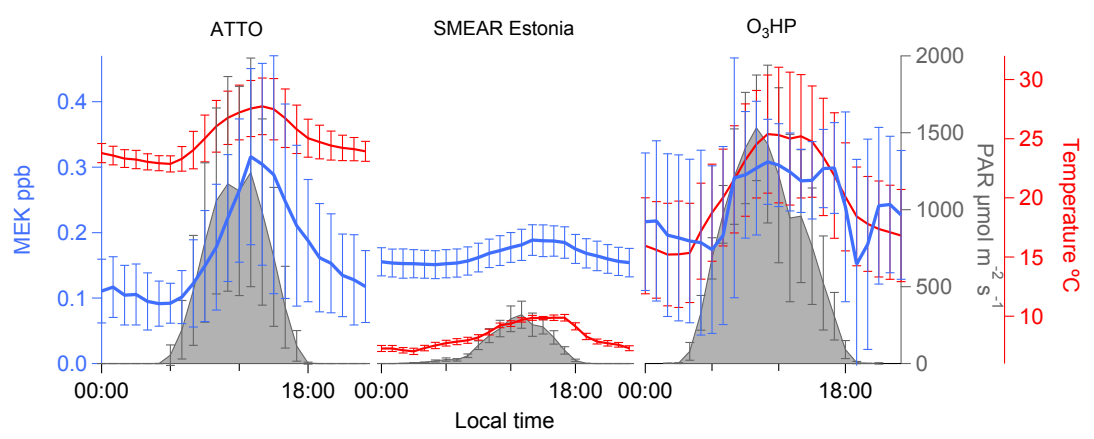

Figure 2. Hourly average diel cycles of MEK at the ATTO (left), SMEAR Estonia (middle) and $\mathrm{O}_{3} \mathrm{HP}$ (right) sites, for the period of measurements (wet season 2014 for ATTO at $38 \mathrm{~m}$ October 2014 for SMEAR Estonia at $16 \mathrm{~m}$, and May and June 2014 for $\mathrm{O}_{3} \mathrm{HP}$ at $2 \mathrm{~m}$ ). Hourly mean diel cycles of temperature and PAR are also shown in red and grey, respectively. Error bars represent the standard deviations.

\subsection{CYPHEX: mixed marine, rural environment influenced by aged air masses (Cyprus)}

The Cyprus Photochemistry Experiment (CYPHEX) campaign took place at a site located in the NW inshore part of Cyprus, in the Paphos region ( $34^{\circ} 57^{\prime} 50.0^{\prime \prime} \mathrm{N}, 32^{\circ} 22^{\prime} 37.0^{\prime \prime} \mathrm{E}$ ) (Fig. 1). The site experiences mixed marine and rural emissions influence. The climate is Mediterranean, warm and dry, and shrubs and small trees dominate the sparse vegetation.

The measurements took place during July and August 2014 without a single rain event. Instruments were installed inside containers and connected to a stack inlet that reached up $5 \mathrm{~m}$ above the container roofs. Air was drawn through the $8 \mathrm{~m}$ stack inlet of $0.5 \mathrm{~m}$ with high flow rate $\left(10 \mathrm{~L} \mathrm{~min}^{-1}\right)$ to minimise wall losses. The subsampling inlet line was made of Teflon (13 mm OD), was insulated and heated to $35^{\circ} \mathrm{C}$, and had a PTFE inlet particle filter. The LOD and uncertainty of the PTR-MS were $0.02 \mathrm{ppb}$ and $11 \%$, respectively.

\section{Results}

\subsection{Sites dominated by biogenic emissions}

All the pristine or remote sites studied were characterised by relatively low mixing ratios of nitrogen oxides $\left(\mathrm{NO}_{x}\right)$ $\left(<3 \mathrm{ppb}\right.$ of nitrogen dioxide $\left(\mathrm{NO}_{2}\right)$ for $\mathrm{O}_{3} \mathrm{HP}$ (Kalogridis et al., 2014; Zannoni et al., 2016), 0.2-0.8 ppb of $\mathrm{NO}_{x}$ for SMEAR Estonia, and $<1 \mathrm{ppb} \mathrm{NO}_{x}$ for the Amazon rainforest (Kuhn et al., 2010)). The diel cycles of MEK at these sites followed a comparable pattern (Fig. 2), where MEK mixing ratios were highest in the middle of the day, following the maxima of light and air temperature. The dominant source at these sites was considered to be biogenic. Mixing ratios of MEK correlated well with ambient temperature $\left(r^{2}=0.57\right.$ (ATTO), $r^{2}=0.83\left(\right.$ SMEAR), $r^{2}=0.47$ $\left(\mathrm{O}_{3} \mathrm{HP}\right)$ ), while it was less well correlated with photosynthetically active radiation (PAR) $\left(r^{2}=0.23\right.$ (ATTO), $r^{2}=0.26$
(SMEAR), $\left.r^{2}=0.67\left(\mathrm{O}_{3} \mathrm{HP}\right)\right)$. This suggests that ambient temperature predominantly influenced MEK emission rates from plants.

The vertical observations at ATTO revealed a strong diel variability in the magnitude and vertical distribution of MEK mixing ratios throughout the forest canopy and in the atmosphere above. Figure 3 shows an example of an hourly vertical profile of MEK for 1 day (7 March 2014) from 13:00 to 15:00 LT, from the ground to the atmosphere, suggesting that the canopy top is the major source of MEK at the site on such days. Similar concentration gradients were found for $83 \%$ (for the afternoon hours) and $45 \%$ (for the morning hours) of all days of measurements. In addition, MEK mixing ratios decreased significantly beneath the canopy towards the forest floor, possibly due to dry deposition or generally smaller vegetation emissions due to less light and temperature. However, a possible production from the ozonolysis of alkanes or bidirectional plant exchange cannot be ruled out. For a seasonal comparison, Yáñez-Serrano et al. (2015) reported $0.43 \mathrm{ppb}$ of MEK for the dry season (September 2013) and $0.13 \mathrm{ppb}$ of MEK for the wet season (February-March 2013) at $38 \mathrm{~m}$. Curiously, at $24 \mathrm{~m}$, MEK mixing ratios for the wet season were $0.38 \mathrm{ppb}$, very close to the measured values for this study. Possible differences in canopy structure temperature and solar radiation among years may be the cause for this discrepancy.

At the TT34 rainforest site, ecosystem-scale fluxes were directly calculated from the PTR-MS measurements using the method of virtual disjunct eddy covariance (vDEC) (Karl et al., 2001; Fig. 4). The fluxes averaged over the entire 11month measurement period (covering parts of both the dry and the wet season) clearly demonstrate an emission of MEK by the rainforest during daytime with the highest emissions around noon, and no emissions during nighttime. In terms of seasonal variation, MEK mixing ratios were observed to be higher during the dry season (September-October 2013, $\sim 0.6 \mathrm{ppb}$ ) and lower during the wet season (January-April, $\sim 0.2 \mathrm{ppb}$ ) (data not shown). 


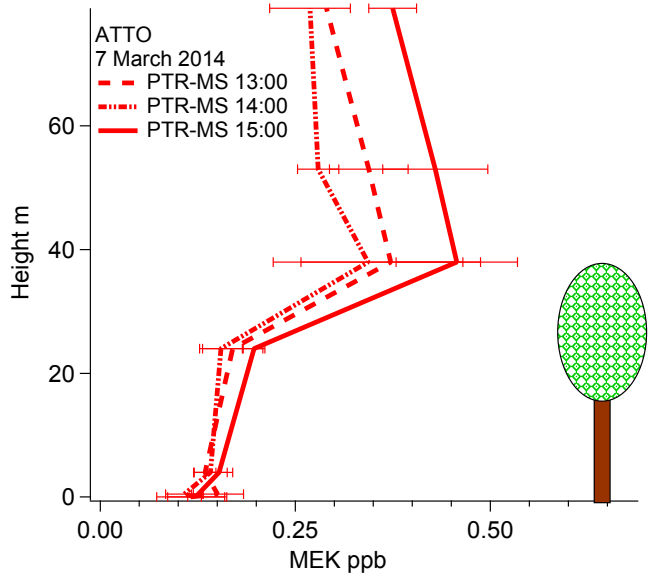

Figure 3. Hourly average vertical profiles of MEK mixing ratios at ATTO for 7 March 2014 for 13:00 LT (dashed lines), 14:00 LT (dotted and dashed lines) and 15:00 LT (thick lines). Error bars of vertical profiles are the standard deviations.

Online ambient mixing ratios of MEK, as measured by the PTR-MS in the hemiboreal forest at the SMEAR Estonia site during autumn 2012, were on average $0.15 \pm 0.04 \mathrm{ppb}$ (range $0.09-0.25 \mathrm{ppb}$ ). These mixing ratios are almost a factor of 2 lower than ATTO and $\mathrm{O}_{3} \mathrm{HP}$ during daytime hours. This difference among boreal forests, with growing season ending in October, broadleaved tropical (ATTO) and temperate $\left(\mathrm{O}_{3} \mathrm{HP}\right)$ forests could be partly related to the temperature dependence of MEK emissions apparently common among all biogenic sites.

The rural Mediterranean temperate forest site at $\mathrm{O}_{3} \mathrm{HP}$ differs significantly from the tropical rainforest (ATTO, TT34) or the hemiboreal forest (SMEAR Estonia, Fig. 1). The trees at $\mathrm{O}_{3} \mathrm{HP}$ are predominantly Quercus pubescens, a high isoprene emitter (Keenan et al., 2009). At this site, the exchange of air through the forest canopy is enhanced because the canopy is sparse. As shown in Fig. 2, ambient MEK mixing ratios measured inside the canopy $(2 \mathrm{~m})$ increased with temperature in the morning. During the day, increased forest emissions of MEK seemed to balance the rise of the boundary layer depth, resulting in a plateau until sunset. The fluctuation of MEK after sunset may be understood as a result of a ceased source revealing the deposition as it can scarcely be explained by gas-phase chemistry or the reduced nocturnal boundary layer height.

During the CANOPÉE campaign at the $\mathrm{O}_{3} \mathrm{HP}$ site, additional GC-FID samples were taken at $2 \mathrm{~m}$, allowing measurements of several anthropogenic light hydrocarbons, including $n$-butane. This sampling was performed in parallel to the PTR-MS measurements. All samples contained $n$-butane, which typically has an anthropogenic origin with an average mixing ratio of $0.071 \pm 0.09$ (much lower mixing ratios than MEK), indicating there is no significant source of $n$-butane nearby. Hence, MEK at the $\mathrm{O}_{3} \mathrm{HP}$ site could not be related to

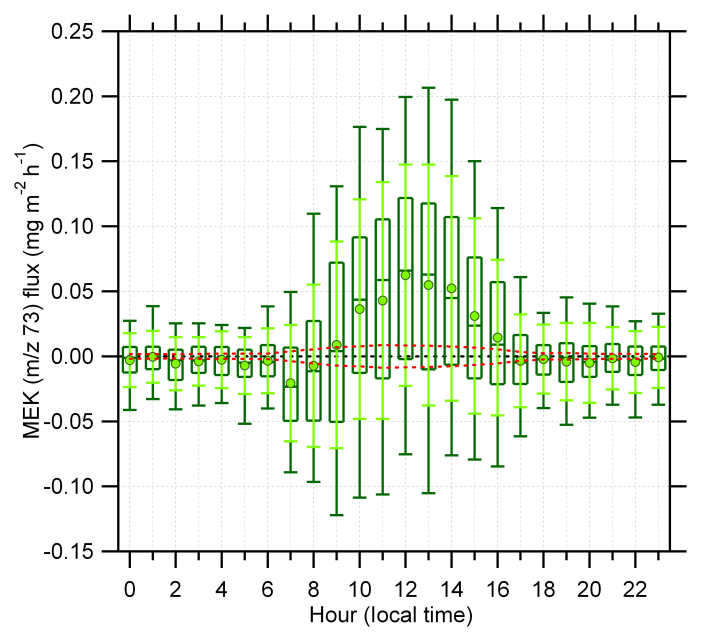

Figure 4. Hourly average MEK fluxes at the TT34 tower for the period September 2013-July 2014. The light-green circles represent means and associated error bars are 1 standard deviation. The central line of the box plots (dark green) indicates the median, the bottom and top lines are the 25 th and 75 th percentile, respectively, and whiskers are the 5th and 95th percentiles. Red dashed lines indicate the propagated limit of detection calculated according to the method outlined by Langford et al. (2015).

the atmospheric oxidation of $n$-butane. Furthermore, the absence of a correlation with other anthropogenic tracers leads us to conclude that MEK at this site was predominantly of biogenic origin.

The measurements obtained by PTR-MS at the presented sites dominated by biogenic emissions were occasionally confirmed by GC-FID and GC-MS, which are compoundselective. At ATTO the same range of MEK mixing ratios for the same hour of the day and height for the GC-FID and the PTR-MS measurements was found, indicating that the PTR-MS signal was only or at least dominated by MEK. To identify sources, canopy measurements at SMEAR Estonia were complemented by emission measurements using cuvettes with GC-MS identification. Common hemiboreal forest species, such as Quercus robur, Tilia cordata, Sorbus aucuparia, Betula pubescens and Picea abies, were screened for VOC emissions. The highest emissions of MEK were found from Tilia cordata and Picea abies (Table 2). The data are consistent with those reported by Bourtsoukidis et al. (2014b), who measured an emission rate of MEK of $2.6 \pm 2.2 \mathrm{ng} \mathrm{g}_{(\mathrm{dw} \text { needles })}^{-1} \mathrm{~s}^{-1}$ from Picea abies using PTRMS. The GC-MS technique obtained a very similar value of $2.3 \mathrm{ng} \mathrm{g}_{\text {(dw needles) }}^{-1} \mathrm{~s}^{-1}$. MEK emissions from Picea abies were relatively small compared to other VOCs emitted by the same plant species such as total monoterpenes and acetone, which reached 93.2 and $27.6 \mathrm{ng} \mathrm{g}_{\text {(dw needles) }}^{-1} \mathrm{~s}^{-1}$, respectively (Bourtsoukidis et al., 2014b). In addition to plant sources, the emissions rates of MEK from leaf litter were quantified using a GC-MS. MEK litter emissions, with a monthly av- 
Table 2. Emission rates of MEK for typical hemiboreal plant species and soil litter measured by GC-MS technique at the SMEAR site.

\begin{tabular}{lrrrrr}
\hline $\begin{array}{l}\text { Plant species and } \\
\text { soil cuvettes }\end{array}$ & $\begin{array}{r}\text { Mean } \\
\mu \mathrm{g} \mathrm{m}^{-2} \mathrm{~h}^{-1}\end{array}$ & $\begin{array}{r}\text { Standard } \\
\text { deviation } \\
\mu \mathrm{g} \mathrm{m}^{-2} \mathrm{~h}^{-1}\end{array}$ & $\begin{array}{r}\text { Standard } \\
\text { error } \\
\mu \mathrm{g} \mathrm{m}^{-2} \mathrm{~h}^{-1}\end{array}$ & $\begin{array}{r}\text { Median } \\
\mu \mathrm{g} \mathrm{m}^{-2} \mathrm{~h}^{-1}\end{array}$ & $\begin{array}{r}\text { Number of } \\
\text { data points } \\
\text { for statistics }\end{array}$ \\
\hline Quercus robur & 8.12 & - & - & - & 1 \\
Tilia cordata & 12.93 & 4.89 & 3.46 & 12.93 & 3 \\
Sorbus aucuparia & 9.08 & - & - & - & 1 \\
Betula pubescens & 9.36 & 5.10 & 2.94 & 8.21 & 3 \\
Picea abies & 13.76 & 5.05 & 2.91 & 15.51 & 3 \\
Leaf litter & 7.00 & 3.37 & 2.11 & 6.58 & 24 \\
\hline
\end{tabular}

erage of $7 \mu \mathrm{g} \mathrm{m}^{-2} \mathrm{~h}^{-1}$, were of comparable magnitude to the emissions rates of MEK from the screened hemiboreal forest tree species, including Quercus robur or Sorbus aucuparia, which emitted $8-9 \mu \mathrm{g} \mathrm{m}^{-2} \mathrm{~h}^{-1}$ of MEK (Table 2).

\subsection{Anthropogenically influenced sites}

Anthropogenically influenced sites are characterised by air masses that have passed over polluted cities or industrialised regions. This air typically has elevated mixing ratios of $\mathrm{NO}_{x}$, other products of fossil fuel combustion such as aromatic compounds, and carbon monoxide (CO), as well as higher aerosol loading. Regional biomass burning plumes can also be a source of anthropogenic input to air masses and are here considered anthropogenic.

The T2 dataset was sorted for polluted periods (air masses loaded with $\mathrm{CO}$, black carbon, high aerosol loading, aromatic compounds) and non-polluted periods. Periods with $\mathrm{CO}$ higher than $130 \mathrm{ppb}$ during the tropical wet season and higher than $160 \mathrm{ppb}$ during the dry season were considered polluted. As shown in Fig. 5, MEK mixing ratios strongly increase with pollution. The T2 site in Brazil is located on the bank of the Rio Negro and is affected by both the tropical rainforest (biogenic) and the megacity of Manaus (anthropogenic). The location of the $\mathrm{T} 2$ site downwind of Manaus and upwind of the rainforest minimises the biogenic influence. MEK mixing ratios were generally lower for the clean conditions at T2 than mixing ratios found at ATTO or TT34 (Figs. 2 and 5). Nevertheless, the mixing ratios of MEK during polluted conditions $(0.7 \pm 0.33 \mathrm{ppb}$ during dry season at 13:00 LT) reached or even exceeded those at the other tropical rainforest sites $(0.32 \pm 0.13 \mathrm{ppb}$ at $13: 00 \mathrm{LT}$ for ATTO and $0.45 \pm 0.28 \mathrm{ppb}$ at TT34; Figs. 2 and 5). Presumably, anthropogenically affected air as transported across the Rio Negro from the city of Manaus ( $\sim 2$ million inhabitants; IBGE, 2014) generated a plume with a mixture of anthropogenic MEK directly emitted in Manaus or MEK formed by oxidation of, for example, $n$-butane during transport. The general trend observed in Fig. 6 is an increase in MEK mixing ratios when easterly winds came from Manaus (located to the east of T2). However, there were times when winds blew from the north, and incident air masses passed through large rainfor- est areas, in which TT34 is included; these air masses then crossed the river and arrived at the site. During these times, when air masses were mostly dominated by biogenic emissions, MEK enhancement reached on average $0.2 \mathrm{ppb}$.

Mixing ratios of MEK at T2 were found to be significantly enhanced during polluted conditions for both dry and wet season (Fig. 7). The relative enhancement within polluted periods at 13:00 LT ranged around a factor of 1.5 for the wet season and of 1.8 for the dry season. During the dry season, the day-to-day variability was more intense, as reflected by the standard deviations which increased by $360 \%$ for the clean conditions and $410 \%$ for the polluted conditions relative to the wet season clean and polluted values, respectively. This may indicate a difference in the sources and sinks regulating MEK mixing ratios among the different seasons. Examples of this difference could be an increase in MEK due to biomass burning, more abundant during the dry season, or changes in the deposition rates due to changes in rain frequency.

The CYPHEX campaign took place at Ineia, north-west Cyprus, at a location that has very little significant vegetation nearby. The air masses that pass through the site are either from western Europe, passing across France and Spain and then the Mediterranean Sea, or from south-eastern Europe (e.g. Turkey, Greece). During the CYPHEX campaign, the hourly median MEK mixing ratios did not show any distinct diel cycle or relations to temperature or net radiation (Fig. 5), strongly suggesting that no significant local sources were present. Furthermore, backward air mass trajectories, as calculated by the HYSPLIT model (NOAA Air Resources Laboratory, USA; Stein et al., 2015) (Fig. 8), can be used to delineate times when Cyprus was affected by easterly and westerly flow. These trajectories were started at $650 \mathrm{~m}$ height with the ensemble mode. The periods (east, west) were chosen on the basis of the FLEXPART model. Further information can be found in Derstroff et al. (2016). On average, easterly air masses contained $0.13 \pm 0.03 \mathrm{ppb}$, whereas westerly masses contained $0.08 \pm 0.02 \mathrm{ppb}$. This difference can be due to differences in source strength, to the greater duration of boundary layer transport from the west and hence marine uptake, or to photochemical loss during transport. 


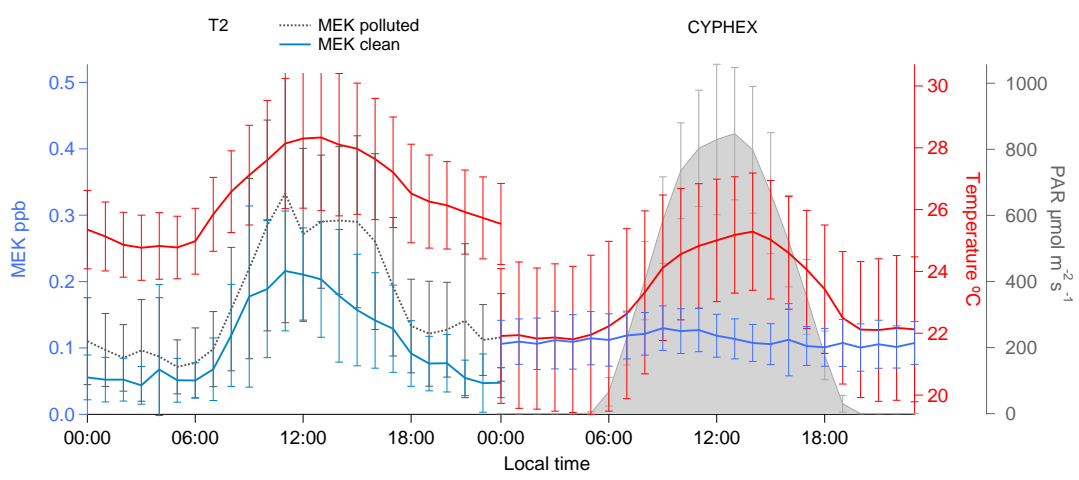

Figure 5. Hourly average diel cycles of MEK at the T2 (left) and CYPHEX (right) sites, for the period of measurements (wet season 2014 for T2 at $14 \mathrm{~m}$, July and August 2014 for CYPHEX at $12 \mathrm{~m}$ ). For T2 a separation between polluted (dotted black line) and clean (thick blue line) air masses was done. Hourly mean diel cycles of temperature and PAR are also shown in red and grey, respectively. Error bars represent the standard deviations.

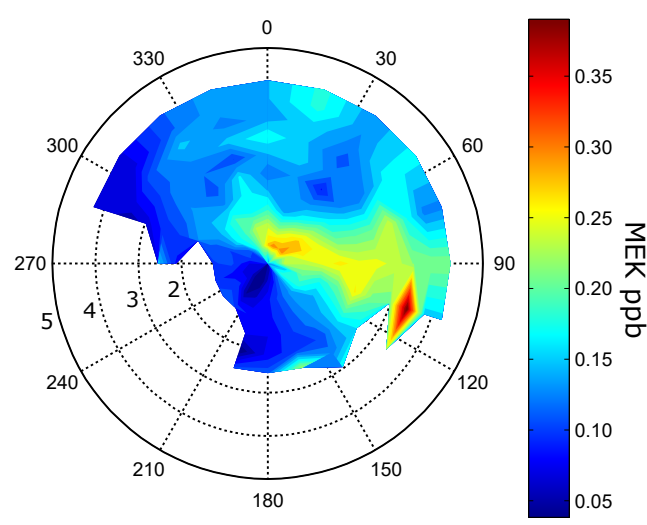

Figure 6. Polar surface plot for average MEK mixing ratios at a given wind direction (angle, $1-5 \mathrm{~m} \mathrm{~s}^{-1}$ ) and wind speed (radius).

\subsection{Compilation of measurement data}

In order to investigate the origin and characteristics of MEK in the atmosphere, we calculated the correlation coefficient $\left(r^{2}\right)$ between the mixing ratios of MEK and other comeasured VOC species for each site (Table 3 ). This coefficient is the ratio of the variability in the MEK mixing ratios to the variability in the other VOC mixing ratios available for each site. The correlation between MEK and other VOC helps to identify possible similarities such as common sources, sinks, chemical mechanisms, or transport processes. However, this comparison does not necessarily claim links between the various compounds. Acetone, acetaldehyde, monoterpenes, isoprene, isoprene oxidation products and methanol are regarded as being mainly of biogenic origin especially in forested areas (Kesselmeier and Staudt, 1999; Laothawornkitkul et al., 2009). Nevertheless, acetone, acetaldehyde and methanol may have additional sources including direct and secondary anthropogenic emissions that cannot be neglected even at clean environments (Goldstein

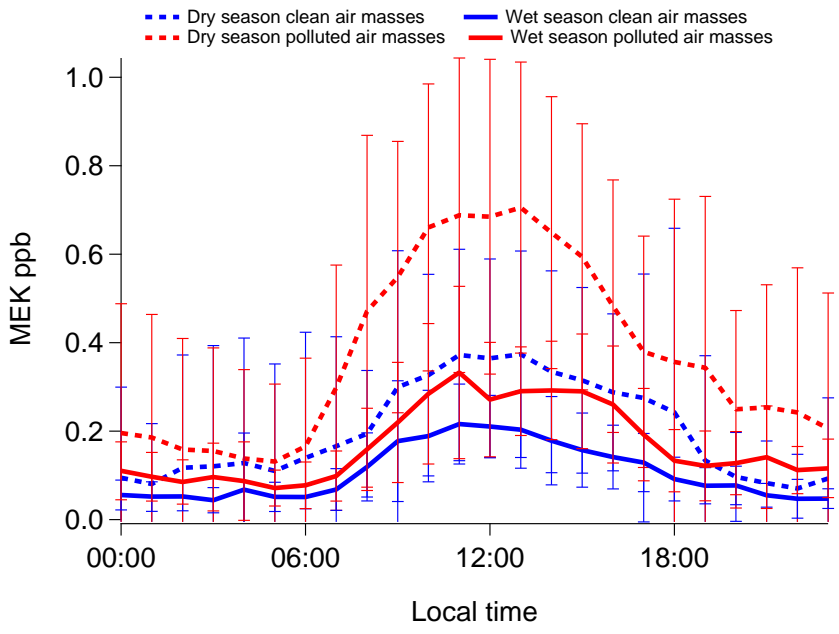

Figure 7. Hourly average concentrations of MEK in ppb for the clean conditions (blue) and the polluted conditions (red) at the T2 site. Dashed lines represent the dry season and thick lines represent the wet season. Error bars represent the standard deviation.

and Schade, 2000; Yáñez-Serrano et al., 2015). Compounds such as benzene, toluene, xylene and acetonitrile are considered typical anthropogenic tracers (Andreae and Merlet, 2001; Finlayson-Pitts and Pitts Jr., 1997).

In general, biogenic sites, namely ATTO, SMEAR Estonia, and $\mathrm{O}_{3} \mathrm{HP}$, showed relatively high correlations between MEK and almost all biogenic VOCs $\left(r^{2}>0.5\right)$. Exceptions appear in the $r^{2}$ values for $\mathrm{O}_{3} \mathrm{HP}$. For instance, the highest correlation coefficient $\left(r^{2}\right)$ was found for MEK and acetone at the SMEAR site $\left(r^{2}=0.97\right)$. A high correlation coefficient could indicate that the atmospheric processes governing acetone and MEK abundance are likely very similar (Zhou and Mopper, 1993). In SMEAR Estonia, overall high correlations were found between MEK and the oxygenated compounds, acetone, acetaldehyde and methanol, as 


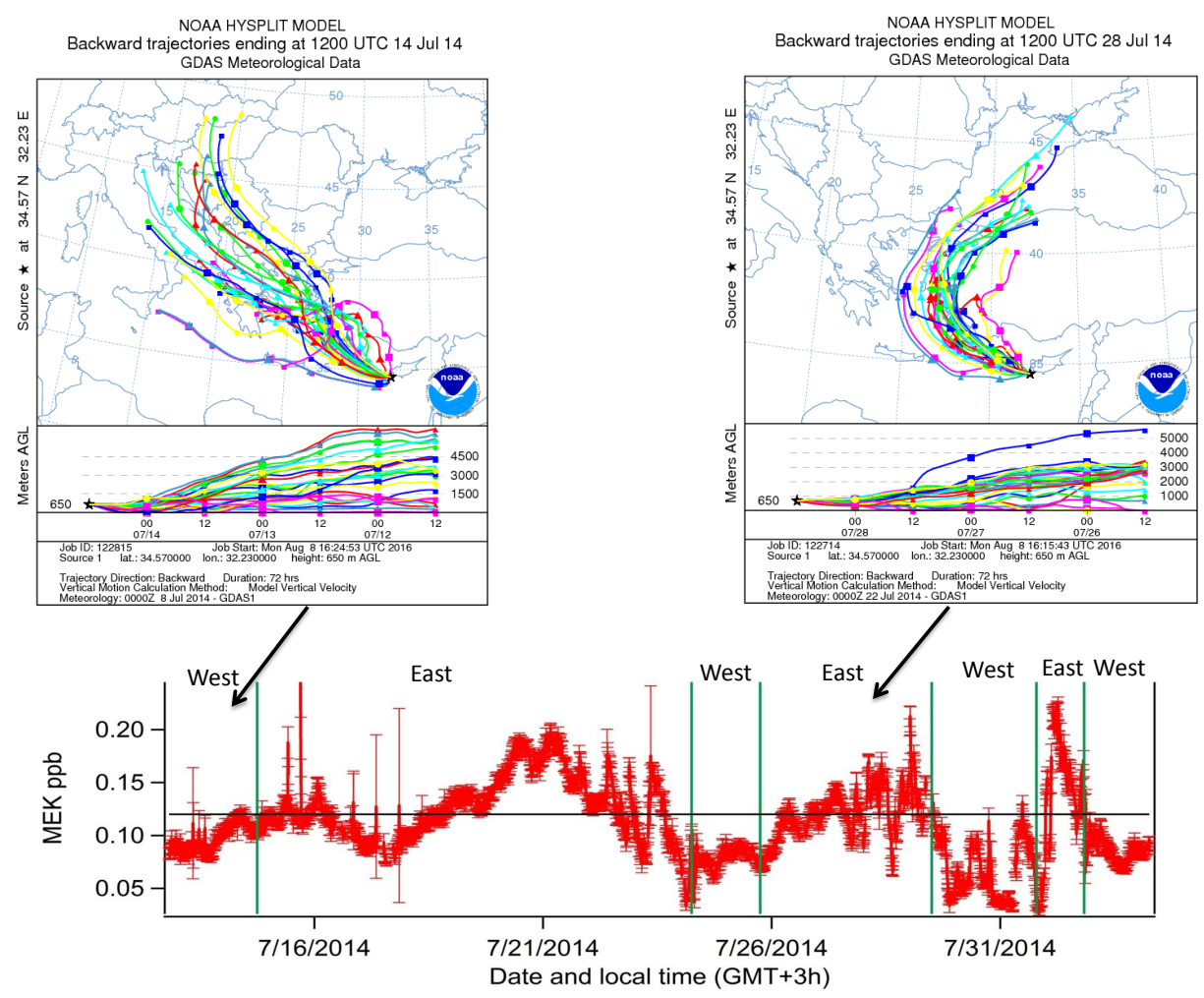

Figure 8. Timeline of MEK mixing ratios divided into periods when the air was coming from either eastern or western Europe. The HYSPLIT backward trajectories from 14 July and 28 August 2014 are shown based on the origin of the air masses. The black line represents the average of the whole campaign.

well as with monoterpenes and isoprene. At ATTO, correlations were only slightly lower. The correlation coefficient $\left(r^{2}\right)$ calculated for the $\mathrm{O}_{3} \mathrm{HP}$ observations were generally lower than for ATTO and SMEAR Estonia, further influenced by the higher turbulent mixing due to sparser vegetation, leading to fastest transport to the atmosphere. Nevertheless, the good correlations of MEK with typical biogenically emitted compounds, such as isoprene, isoprene oxidation products, monoterpenes, methanol and acetone, corroborated the biogenic origin of MEK emissions at the biogenic sites.

At the anthropogenically influenced sites, T2 and CYPHEX, correlation coefficient $\left(r^{2}\right)$ for the biogenic compounds were generally lower, apart from the $r^{2}(0.64$ and 0.45 , respectively) between MEK and acetone. It is important to note that although $\mathrm{T} 2$ is a mixed anthropogenic and biogenic site, the correlation coefficient $\left(r^{2}\right)$ was high for MEK and acetone but very low for the rest of the biogenic compounds. For the anthropogenic compounds, T2 had an $r^{2}$ of 0.27 for MEK and acetonitrile and MEK and xylene. Furthermore, the data from the Cyprus site showed poor correlation of MEK with any biogenic compound but a correlation coefficient of $r^{2}=0.58$ for MEK and toluene, an anthropogenic tracer.

\section{Discussion}

\subsection{PTR-MS measurements}

Most of the measurements in this study were performed with a quadrupole PTR-MS, a technique that monitors selected VOC ions, online and with fast time response. A disadvantage is the separation by masses with a mass resolution of only $1 \mathrm{amu}$. For some masses, several compounds and/or compound fragments may be detected as one signal. The quadrupole PTR-MS signal at $m / z 73$ is attributed to MEK, but may have contributing signals of water clusters (de Gouw and Warneke, 2007), butanal (Inomata et al., 2010; McKinney et al., 2011; Slowik et al., 2010; Warneke et al., 2007), acrylic acid (de Gouw et al., 2003), 2-methyl propanal (Baraldi et al., 1999; Jardine et al., 2010), and methyl glyoxal (Holzinger et al., 2007; Jordan et al., 2009b). We have tried to take into account possible interferences by using different analytical techniques and supplementary information. At the SMEAR Estonia site, the accompanying GC-MS observations validated the signal for MEK. Additionally, the GC-FID samples taken at ATTO corroborated the signal for MEK at this site. Nevertheless, we try to give a short overview below about the interferences of other trace gases with the PTR-MS identification of MEK. 
Table 3. Correlation coefficients $\left(r^{2}\right)$ of MEK with other co-measured VOC at the sites investigated. The correlations above 0.5 are colourcoded with warmest colours for highest correlation coefficients. Correlation coefficients $\left(r^{2}\right)$ for the TT34 site in Amazonia are missing due to lack of data.

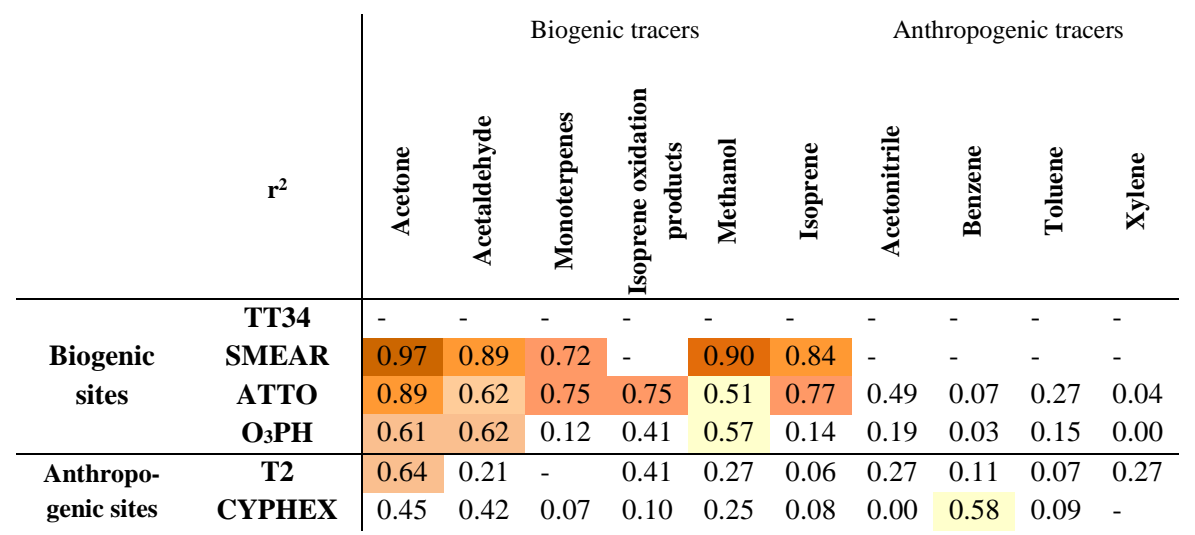

Methyl glyoxal is a likely contributor to the observed signal at the PTR-MS protonated mass $m / z 73$, especially in areas where there are high levels of isoprene. It is formed following the oxidation of methyl vinyl ketone and methacrolein, which are both isoprene oxidation products (Calvert and Madronich, 1987; Lee et al., 2006). Supported by GC-FID measurements and relatively low isoprene levels during the wet season (Yáñez-Serrano et al., 2015), we can assume that the contribution of methyl glyoxal to this mass was insignificant at the rainforest sites (ATTO and TT34). Despite the high isoprene emissions at $\mathrm{O}_{3} \mathrm{HP}$, the correlation between MEK and the isoprene oxidation products was low $\left(r^{2}=0.41\right)$, suggesting that methyl glyoxal did not significantly contribute to the signal at $m / z$ 73. During the CYPHEX campaign the PTR-ToF-MS could unambiguously distinguish between MEK and methyl glyoxal (at 73.0648 and $73.0284 \mathrm{amu}$, respectively).

Even though a contribution of butanal to $m / z 73$ of up to $65 \%$ (Lindinger et al., 1998) and $20 \%$ (Williams et al., 2001) has been reported previously, most butanal fragments on $m / z 57$ (Ionicon Analytic GmbH). Acrylic acid, a marine compound (Liu et al., 2016) that may interfere at $m / z 73$, was probably not of relevance at sites under biogenic influence. However, in the case of anthropogenically influenced sites, such as T2, interferences may have been of relevance. Karl et al. (2007) and Ciccioli et al. (2014) measured tropical biomass burning emissions and found that $m / z 73$ is comprised of $74 \%$ MEK and $23 \%$ 2-methyl propanal (73.1057 amu). Even though none of the sites presented in this study was severely influenced by biomass burning, we cannot completely rule out a possible direct emission of 2-methyl propanal by plants, which is of lower magnitude than from biomass burning (Hafner et al., 2013; Jardine et al., 2010; Karl et al., 2005a). Due to the standard operation conditions of the PTR-MS under our measurement conditions, we neglected water clusters as they are regarded to be insignificant (McKinney et al., 2011; Yáñez-Serrano et al., 2015). To summarise these issues, we note that several studies have concluded $m / z 73$ to originate from MEK only (Bourtsoukidis et al., 2014b; Crutzen et al., 2000; De Gouw et al., 1999, 2000; Holzinger et al., 2000; Karl et al., 2001, 2005a; Kim et al., 2015; Millet et al., 2015; Steeghs et al., 2004). Based on these considerations and the similarity of magnitudes measured by the PTR-MS as compared with the GC results, we assume $m / z 73$ is representative of the atmospheric MEK present.

\subsection{The biogenic MEK}

The data obtained at the biologically influenced sites demonstrated that MEK was emitted by vegetation. This is clearly supported by the canopy-scale net flux observations of MEK at the TT34 rainforest site (Fig. 4) as well as the diel cycles of the mixing ratios at the other biogenically influenced sites (Fig. 2). Furthermore, the leaf-level cuvette measurements at SMEAR Estonia also corroborated the MEK emission by vegetation. In addition, a contribution by other biogenic sources such as dead and decaying plant matter was also observed at SMEAR Estonia to be of similar magnitude to boreal plant species emissions and indicative of a source from plant litter, in accordance with the results from Warneke et al. (1999) that measured MEK emission from the abiotic processes of plant decaying matter. This is not the case for the tropical sites where vertical profiles show that canopy emissions dominate.

High correlation coefficients suggested strong relations between the emission processes for MEK and other biogenic compounds (Table 3). A similar approach has been used previously by Goldstein and Schade (2000) to unveil the sources of acetone. Similarly, Davison et al. (2008) found a high correlation coefficient between MEK and acetone of $r^{2}=0.87$ and a relatively poor correlation between MEK 
and monoterpenes $\left(r^{2}=0.54\right)$. They surmised that good correlations indicated a common origin for biogenically emitted compounds. Furthermore, a resemblance of the pattern of acetone and MEK has been reported for the ATTO site before (Yáñez-Serrano et al., 2015). In our study, we found high correlation coefficients $\left(r^{2}\right)$ for MEK with acetone and MEK with temperature, and lower $r^{2}$ for MEK and compounds such as isoprene and monoterpenes for all the biogenic sites (Table 3). This could indicate that MEK forest emissions are more related to processes resembling acetone emissions and temperature-dependent processes, rather than lightand temperature-dependent emission mechanisms, as for isoprene and monoterpenes (Jardine et al., 2015; Kesselmeier and Staudt, 1999).

Plant physiological production pathways have been reported for MEK formation. MEK can be formed, similarly to acetone, as a by-product of a cyanohydrin lyase reaction during cyanogenesis (Fall, 2003; Vetter, 2000). This chemical defence pathway was also identified in clover by Kirstine et al. (1998) and de Gouw et al. (1999) as a result of mechanical stress, and can be of special importance for tropical rainforests (Miller et al., 2006). On the other hand, in places such as SMEAR Estonia, dominating plant species are not cyanogenic, and other processes for MEK formation are probably more dominant. In pine trees, acetone is produced from light-dependent and independent processes that can be associated with the decarboxylation of acetoacetate occurring in microorganisms and animals (Fall, 2003), from oxidation of fatty acids leading to ketone emissions (Niinemets et al., 2014), from pyruvic acid leading to acetyl-CoA (Kesselmeier and Staudt, 1999), or from uncharacterised biochemical reactions (Fall, 2003). Such processes could also be related to MEK emissions.

Even though extensive laboratory measurements are needed to identify the dominant plant process or processes responsible for MEK emission, this study demonstrated the role that temperature can exert on such emissions. Hence, forests around the world may act as very different sources for atmospheric MEK. This can be seen for boreal forests (SMEAR Estonia), with distinctly lower temperatures, where MEK levels were significantly lower. However, other factors must be considered (Schade et al., 2011), such as leaf area index (LAI) and plant species composition, as well as the environmental factors, water availability and mechanical stress, the latter having already been observed by de Gouw et al. (1999) to act as a driver for MEK emissions.

Due to its relatively long atmospheric lifetime ( $\sim 5$ days for the reaction with $\mathrm{OH}$; Grant et al., 2008), MEK is expected to accumulate in the atmosphere until removal. Hence, atmospheric mixing ratios can reflect seasonality and changes in dominating sources, affected by radiation, temperature and phenology, from more biogenic dominance during the wet season to transport phenomena and oxidation processes of primarily emitted compounds from regional biomass burning, as was seen in 2013 at the ATTO site
(Yáñez-Serrano et al., 2015). Moreover, a possible production from certain terpenes through ozonolysis cannot be excluded (Holzinger et al., 2005). Additionally, the canopy structure seems to be important for air mixing and transport, as seen for the $\mathrm{O}_{3} \mathrm{HP}$ site with an apparently faster mixing due to sparser vegetation and consequent dampening of the amplitude of the diel cycle. Furthermore, due to its oxygenated nature, partitioning to and from aqueous surfaces is likely, including deposition and surface reactions. Its high water solubility might allow dissolution within leaf water (Sander, 2015), triggering bidirectional exchange of MEK (Karl et al., 2005b; McKinney et al., 2011; Niinemets et al., 2014). Due to its high solubility in water and its relatively long lifetime, MEK could potentially influence gas-aqueous reactions on aerosol surfaces (Nozière, 2005). This has been shown indirectly by the production of methyl glyoxal after its oxidation by $\mathrm{OH}$, having implications for the formation of organics in the aerosol aqueous phase (Rodigast et al., 2016).

\subsection{The anthropogenic MEK}

A clear difference could be observed between the anthropogenic and biogenic influenced sites presented in this study. The $\mathrm{T} 2$ site represented a site with mixed influence by urban area and tropical rainforest. Affected by anthropogenic and biogenic sources, ambient mixing ratios of MEK were higher than at the pristine ATTO rainforest site. Polluted episodes (from the Manaus plume) with an increase in MEK could be distinguished for both the wet and the dry season, suggesting a short-range transport of air masses. On the other hand, when the wind is blowing from the north, MEK mixing ratios were also present, showing an influence from biogenic forest emissions (Fig. 7), thus having a mix of biogenic and anthropogenic influence at the T2 site. A strong seasonality of MEK mixing ratios at $\mathrm{T} 2$ reflected biomass burning as a common occurrence in the Amazon region during the dry season (Artaxo et al., 2013). In addition to MEK, a higher contribution of butanal affecting $m / z 73$ (Inomata et al., 2010; Karl et al., 2007) might be possible, although MEK has been reported to have a much higher emission factor (range from 0.17 to 0.83 ) than butanal (range from 0.04 to 0.21 ) for biomass burning (Andreae and Merlet, 2001).

We regarded CYPHEX as an anthropogenically influenced site with weak or no apparent direct sources but which was affected by anthropogenic air masses after long-range transport over marine areas. Losses by transport over the sea and chemical decomposition led to the lowest averaged MEK mixing ratios of all compared sites. Correlation coefficients $\left(r^{2}\right)$ of MEK with the biogenic tracers were relatively poor for T2 and CYPHEX. However, correlations were also poor for the anthropogenic tracers, although slightly better than at the biogenic sites. MEK showed highest correlation with acetone, indicating similar sources and fate in air mixing and chemistry processes. MEK transported over long distances (10 days) is lost by photochemical aging or 
Table 4. Literature compilation of MEK mixing ratios measurements in different ecosystems around the globe from a wide range of atmospheric environments.

\begin{tabular}{|c|c|c|c|c|c|}
\hline Reference & $\begin{array}{l}\text { MEK mixing } \\
\text { ratio in ppb }\end{array}$ & $\begin{array}{l}\text { Type of } \\
\text { environment }\end{array}$ & $\begin{array}{l}\text { Reported } \\
\text { data }\end{array}$ & $\begin{array}{l}\text { Height from } \\
\text { surface }\end{array}$ & $\begin{array}{l}\text { Time of } \\
\text { measurement }\end{array}$ \\
\hline $\begin{array}{l}\text { Zhou and Mopper } \\
\text { (1993) }\end{array}$ & 0.03 & Caribbean Sea & $\begin{array}{l}\text { Cruise data, total } \\
\text { average }\end{array}$ & $10 \mathrm{~m}$ & October 1988 \\
\hline Ho et al. (2002) & 0.14 & $\begin{array}{l}\text { Hong Kong urban cen- } \\
\text { tre }\end{array}$ & Annual average & $6 \mathrm{~m}$ & $\begin{array}{l}\text { April 2000-April } \\
2001\end{array}$ \\
\hline $\begin{array}{l}\text { Cecinato et } \\
\text { al. }(2002)\end{array}$ & 0.15 & $\begin{array}{l}\text { Algerian rural residen- } \\
\text { tial site }\end{array}$ & Daytime average & Not specified & January 2001 \\
\hline $\begin{array}{l}\text { Cecinato et } \\
\text { al. (2002) }\end{array}$ & 0.23 & $\begin{array}{l}\text { Algerian rural residen- } \\
\text { tial site }\end{array}$ & Daytime average & Not specified & August 2001 \\
\hline Feng et al. (2004) & 2.11 & Chinese urban site & Evening time & Not specified & $\begin{array}{l}\text { August- } \\
\text { September } \\
2002\end{array}$ \\
\hline Hellén et al. (2004) & 0.073 & $\begin{array}{l}\text { Finnish boreal forest } \\
\text { site }\end{array}$ & Diel average & $1 \mathrm{~m}$ & $\begin{array}{l}\text { March-April } \\
2003\end{array}$ \\
\hline Sighn et al. (2004) & 0.12 & $\begin{array}{l}\text { Tropospheric Pacific } \\
\text { Ocean }\end{array}$ & Not specified & $0-2 \mathrm{~km}$ & $\begin{array}{l}\text { February-April } \\
2001\end{array}$ \\
\hline Legreid et al. (2007) & $0.2^{\mathrm{a}}$ & Swiss urban site & Annual average & $8 \mathrm{~m}$ & Throughout 2005 \\
\hline Davison et al. (2008) & $0.8^{\mathrm{b}}$ & $\begin{array}{l}\text { Swiss permanent grass- } \\
\text { land site }\end{array}$ & Daytime average & $1.2 \mathrm{~m}$ & June 2005 \\
\hline Grant et al. (2008) & $\sim 0.5$ & Senegalese rural site & Daytime average & $6 \mathrm{~m}$ & September 2006 \\
\hline Jordan et al. (2009b) & 0.13 & USA mixed rural site & $\begin{array}{l}\text { Interannual median } \\
\text { from } 2005 \text { to } 2008\end{array}$ & $12 \mathrm{~m}$ & $\begin{array}{l}\text { From } 2005 \text { to } \\
2008\end{array}$ \\
\hline Kim et al. (2015) & $\sim 4$ & $\begin{array}{l}\text { South Korean semi- } \\
\text { rural site }\end{array}$ & Diel average & $15 \mathrm{~m}$ & June 2013 \\
\hline $\begin{array}{l}\text { Yáñez-Serrano et } \\
\text { al. (2015) }\end{array}$ & 0.43 & $\begin{array}{l}\text { Brazilian tropical rain- } \\
\text { forest site (ATTO) }\end{array}$ & Daytime average & $38 \mathrm{~m}$ & September 2013 \\
\hline $\begin{array}{l}\text { Yáñez-Serrano et } \\
\text { al. (2015) }\end{array}$ & 0.13 & $\begin{array}{l}\text { Brazilian tropical rain- } \\
\text { forest site (ATTO) }\end{array}$ & Daytime average & $38 \mathrm{~m}$ & $\begin{array}{l}\text { February-March } \\
2013\end{array}$ \\
\hline This study & 0.39 & $\begin{array}{l}\text { Brazilian tropical rain- } \\
\text { forest site (ATTO) }\end{array}$ & Daytime average & $38 \mathrm{~m}$ & $\begin{array}{l}\text { February-March } \\
2014\end{array}$ \\
\hline This study & 0.39 & $\begin{array}{l}\text { Brazilian tropical rain- } \\
\text { forest site (TT34) }\end{array}$ & Daytime average & $41 \mathrm{~m}$ & $\begin{array}{l}\text { September } \\
\text { 2013-July } 2014\end{array}$ \\
\hline This study & 0.19 & $\begin{array}{l}\text { Hemiboreal forest site } \\
\text { (SMEAR Estonia) }\end{array}$ & Daytime average & $16 \mathrm{~m}$ & October 2012 \\
\hline This study & 0.30 & $\begin{array}{l}\text { French Mediterranean } \\
\text { forest }\left(\mathrm{O}_{3} \mathrm{HP}\right)\end{array}$ & Daytime average & $2 \mathrm{~m}$ & May-June 2014 \\
\hline This study & 0.13 & $\begin{array}{l}\text { Brazilian mixed tropi- } \\
\text { cal rainforest site (T2) }\end{array}$ & Daytime average & $14 \mathrm{~m}$ & $\begin{array}{l}\text { February- } \\
\text { October } 2014\end{array}$ \\
\hline This study & 0.11 & $\begin{array}{l}\text { Cyprian rural site } \\
\text { (CYPHEX) }\end{array}$ & Daytime average & $8 \mathrm{~m}$ & $\begin{array}{l}\text { July-August } \\
2014\end{array}$ \\
\hline
\end{tabular}

a Average from different seasons reported. ${ }^{b}$ Average of different conditions cutting, a day after cutting and removing hay and a day after removing hay. 
deposition as evidenced by the lowest values reported from CYPHEX. This is despite known secondary photochemical sources, i.e. $n$-butane oxidation (Katzenstein et al., 2003; Kwok et al., 1996). Interestingly, even under polluted conditions, MEK did not correlate with aromatic compounds, except during CYPHEX, although this correlation deteriorated in the more aged westerly air masses. This can only be understood as a result of a very complex mixture of anthropogenic sources of MEK which vary from direct emission by industry (Legreid et al., 2007), gasoline combustion (Verschueren, 1983), biomass burning (Andreae and Merlet, 2001) and vehicular emissions (Brito et al., 2015). Furthermore, chemical processing during transport may contribute, such as oxidation of $n$-butane; however, the longer transport times during CYPHEX from the west corresponded to lower values.

\section{Remarks and conclusions}

The comparison of MEK mixing ratios in different parts of the world is necessary in order to understand how this ubiquitous compound occurs and behaves in the atmosphere. To summarise, Table 4 aims to provide a numerical comparison of MEK mixing ratios reported around the globe. While MEK mixing ratios in our study are relatively constant, MEK has been measured in many different ecosystems ranging from $0.073 \mathrm{ppb}$ to $4 \mathrm{ppb}$. Therefore, it is important to consider the variability in this compound as MEK can lead to PAN and ozone formation in the atmosphere (Pinho et al., 2005). Photochemical odd-hydrogen production in the upper troposphere (Atkinson, 2000; Baeza Romero et al., 2005; De Gouw et al., 1999) can further enhance the MEK ozone forming potential (Folkins et al., 1998; Prather and Jacob, 1997). Of the widely used atmospheric chemistry models, only GEOS-Chem explicitly computes MEK but only with regard to anthropogenic origin. On the basis of the data presented here from forest sites, it is necessary for atmospheric chemistry models to also include biogenic MEK emissions to better estimate its effects on the environment. Sites under biogenic influence showed marked diel variability, matching biogenic VOC emissions and temperature. Structural forest features seem to affect turbulent mixing and diluting of trace gases like MEK, as in the case of $\mathrm{O}_{3} \mathrm{HP}$ with patchy vegetation. MEK seemed to be produced in plants in a similar fashion to acetone, likely released during mechanical stress. Possible pathways for productions in plants are oxidation of fatty acids, cyanogenesis, production from pyruvic acid leading to acetyl-CoA, and light-dependent and independent processes that can be associated with the decarboxylation of acetoacetate occurring in microorganisms and animals.
This study presents the first compilation and comparison of ambient measurements of MEK at different sites. MEK patterns and mixing ratios differ around the globe depending on sources and transport. Vegetation and litter have been identified as sources of MEK and magnitude of sources varied among the tropical rainforest, the Mediterranean temperate forest and the hemiboreal forest following a likely temperature dependence. However, via different filtering methodologies (CO filtering and backward trajectories), the anthropogenic input from polluted regions, such as the mixed urban and tropical rainforest and mixed marine environment, is often found to be the dominant contribution.

\section{Data availability}

Even though the data are still not available in any public repository, as the authors are still working on other parts of the data collected during the campaigns, the data are available upon request from the main author.

Acknowledgements. For ATTO, we thank the Max Planck Society and the Instituto Nacional de Pesquisas da Amazonia for continuous support. Furthermore, we acknowledge the support by the ATTO project (German Federal Ministry of Education and Research, BMBF funds 01LB1001A; Brazilian Ministério da Ciência, Tecnologia e Inovação FINEP/MCTI contract 01.11.01248.00), UEA and FAPEAM, LBA/INPA, and SDS/CEUC/RDS-Uatumã. We would especially like to thank all the people involved in the logistical support of the ATTO project, in particular Reiner Ditz and Hermes Braga Xavier. We acknowledge the micrometeorological group of INPA/LBA for their collaboration concerning the meteorological parameters, with special thanks to Marta Sá, Antonio Huxley and Leonardo Oliveira. We would like to acknowledge Stefan Wolff for the construction, support and maintenance of the inlet system. We are grateful to Nina Knothe for logistical help. We would also like to thank Thomas Klüpfel for all the great support provided with the PTR-MS operation in the laboratory as well as in the field. This paper contains results of research conducted under the Technical/Scientific Cooperation Agreement between the National Institute for Amazonian Research, the State University of Amazonas, and the Max-Planck-Gesellschaft e.V.; the opinions expressed are the entire responsibility of the authors and not of the participating institutions.

For TT34, we thank the Natural Environment Research Council for funding the CLAIRE-UK project (reference NE/I012567/1), A. Valach, B. Davison and M. Shaw for assistance and A. R. MacKenzie for valuable discussions.

For SMEAR, we would like to acknowledge the EU Regional Development Foundation: "Environmental Conservation and Environmental Technology R\&D Programme" project BioAtmos (3.2.0802.11-0043), "Internationalization of Science Programme" project INSMEARIN (10.1-6/13/1028), and the "Estonian Research Infrastructures Roadmap" project Estonian Environmental Observatory (3.2.0304.11-0395). We express our gratitude to the Archimedes Foundation (international programme DoRa) and the "Freunde und Förderer der Goethe Universität" that provided funding to E. Bourtsoukidis for conducting research in Estonia. We 
would like to additionally thank Dominika Radacki, Javier Roales, Beate Noe, Eero Talts, Ahto Kangur and Miguel P. Estrada for providing valuable help with the setup and transportation. Special thanks to Boris Bonn for the insightful discussions and comments during the production of this article.

For $\mathrm{O}_{3} \mathrm{HP}$, the measurements presented in this study were supported by the European Commission's 7th Framework Programme under grant agreement number 287382 "PIMMS", as well as by ANR-CANOPEE and ChArMEx, CEA and CNRS. We acknowledge B. Bonsang and C. Kalogridis for the GC-FID measurements, J. P. Orts and I. Reiter for logistical support, and J. Lathière for managing the CANOPÉE project.

For T2, we thank Bruno Takeshi for all the logistical support. Furthermore, we acknowledge the support by FAPESP grant 2013/25058-1 and 2013/05014-0.

For CYPHEX, the authors gratefully acknowledge the NOAA Air Resources Laboratory (ARL) for the provision of the HYSPLIT transport and dispersion model and READY website (http://www.ready.noaa.gov) used in this publication.

The article processing charges for this open-access publication were covered by the Max Planck Society.

Edited by: E. Harris

Reviewed by: two anonymous referees

\section{References}

Andreae, M. O. and Merlet, P.: Emission of trace gases and aerosols from biomass burning, Global Biogeochem. Cy., 15, 955-966, doi:10.1029/2000gb001382, 2001.

Andreae, M. O., Acevedo, O. C., Araùjo, A., Artaxo, P., Barbosa, C. G. G., Barbosa, H. M. J., Brito, J., Carbone, S., Chi, X., Cintra, B. B. L., da Silva, N. F., Dias, N. L., Dias-Júnior, C. Q., Ditas, F., Ditz, R., Godoi, A. F. L., Godoi, R. H. M., Heimann, M., Hoffmann, T., Kesselmeier, J., Könemann, T., Krüger, M. L., Lavric, J. V., Manzi, A. O., Lopes, A. P., Martins, D. L., Mikhailov, E. F., Moran-Zuloaga, D., Nelson, B. W., Nölscher, A. C., Santos Nogueira, D., Piedade, M. T. F., Pöhlker, C., Pöschl, U., Quesada, C. A., Rizzo, L. V., Ro, C.-U., Ruckteschler, N., Sá, L. D. A., de Oliveira Sá, M., Sales, C. B., dos Santos, R. M. N., Saturno, J., Schöngart, J., Sörgel, M., de Souza, C. M., de Souza, R. A. F., Su, H., Targhetta, N., Tóta, J., Trebs, I., Trumbore, S., van Eijck, A., Walter, D., Wang, Z., Weber, B., Williams, J., Winderlich, J., Wittmann, F., Wolff, S., and Yáñez-Serrano, A. M.: The Amazon Tall Tower Observatory (ATTO): overview of pilot measurements on ecosystem ecology, meteorology, trace gases, and aerosols, Atmos. Chem. Phys., 15, 10723-10776, doi:10.5194/acp-15-10723-2015, 2015.

Artaxo, P., Rizzo, L. V., Brito, J. F., Barbosa, H. M. J., Arana, A., Sena, E. T., Cirino, G. G., Bastos, W., Martin, S. T., and Andreae, M. O.: Atmospheric aerosols in Amazonia and land use change: from natural biogenic to biomass burning conditions, Faraday Discuss., 165, 203-235, doi:10.1039/c3fd00052d, 2013.

Atkinson, R.: Atmospheric chemistry of VOCs and $\mathrm{NO}_{x}$, Atmos. Environ., 34, 2063-2101, doi:10.1016/s1352-2310(99)00460-4, 2000 .
Atkinson, R. and Arey, J.: Gas-phase tropospheric chemistry of biogenic volatile organic compounds: A review, Atmos. Environ., 37, S197-S219, doi:10.1016/S1352-2310(03)00391-1, 2003.

Baeza Romero, M. T., Blitz, M. A., Heard, D. E., Pilling, M. J., Price, B., Seakins, P. W., and Wang, L.: Photolysis of methylethyl, diethyl and methylvinyl ketones and their role in the atmospheric $\mathrm{HO}_{x}$ budget, Faraday Discuss., 130, 73-88, doi:10.1039/b419160a, 2005.

Baraldi, R., Rapparini, F., Rossi, F., Latella, A., and Ciccioli, P.: Volatile organic compound emissions from flowers of the most occuring and economically important species of fruit trees, Phys. Chem. Earth B, 24, 729-732, doi:10.1016/S14641909(99)00073-8, 1999.

Bon, D. M., Ulbrich, I. M., de Gouw, J. A., Warneke, C., Kuster, W. C., Alexander, M. L., Baker, A., Beyersdorf, A. J., Blake, D., Fall, R., Jimenez, J. L., Herndon, S. C., Huey, L. G., Knighton, W. B., Ortega, J., Springston, S., and Vargas, O.: Measurements of volatile organic compounds at a suburban ground site (T1) in Mexico City during the MILAGRO 2006 campaign: measurement comparison, emission ratios, and source attribution, Atmos. Chem. Phys., 11, 2399-2421, doi:10.5194/acp-11-23992011, 2011.

Bourtsoukidis, E., Williams, J., Kesselmeier, J., Jacobi, S., and Bonn, B.: From emissions to ambient mixing ratios: online seasonal field measurements of volatile organic compounds over a Norway spruce-dominated forest in central Germany, Atmos. Chem. Phys., 14, 6495-6510, doi:10.5194/acp-14-6495-2014, 2014a.

Bourtsoukidis, E., Bonn, B., and Noe, S. M.: On-line field measurements of BVOC emissions from Norway spruce (Picea abies) at the hemiboreal SMEAR-Estonia site under autumn conditions, Boreal Environ. Res., 19, 153-167, 2014b.

Bracho-Nunez, A., Knothe,, N. M., Welter, S., Staudt, M., Costa, W. R., Liberato, M. A. R., Piedade, M. T. F., and Kesselmeier, J. Leaf level emissions of volatile organic compounds (VOC) from some Amazonian and Mediterranean plants, Biogeosciences, 10, 5855-5873, doi:10.5194/bg-10-5855-2013, 2013.

Brilli, F., Gioli, B., Zona, D., Pallozzi, E., Zenone, T., Fratini, G., Calfapietra, C., Loreto, F., Janssens, I. A., and Ceulemans, R.: Simultaneous leaf- and ecosystem-level fluxes of volatile organic compounds from a poplar-based SRC plantation, Agr. Forest Meteorol., 187, 22-35, doi:10.1016/j.agrformet.2013.11.006, 2014.

Brito, J., Wurm, F., Yáñez-Serrano, A. M., de Assunção, J. V., Godoy, J. M., and Artaxo, P.: Vehicular Emission Ratios of VOCs in a Megacity Impacted by Extensive Ethanol Use: Results of Ambient Measurements in São Paulo, Brazil, Environ. Sci. Technol., 49, 11381-11387, doi:10.1021/acs.est.5b03281, 2015.

Calvert, J. G. and Madronich, S.: Theoretical study of the initial products of the atmospheric oxidation of hydrocarbons, J. Geophys. Res., 92, 2211, doi:10.1029/JD092iD02p02211, 1987.

Cecinato, A., Yassaa, N., Di Palo, V., and Possanzini, M.: Observation of volatile and semi-volatile carbonyls in an Algerian urban environment using dinitrophenylhydrazine/silica-HPLC and pentafluorophenylhydrazine/silica-GC-MS, J. Environ. Monitor., 4, 223-228, doi:10.1039/b110616n, 2002.

Chew, A. A. and Atkinson, R.: OH radical formation yields from the gas-phase reactions of $\mathrm{O}_{3}$ with alkenes and monoterpenes, $\mathrm{J}$. Geophys. Res., 101, 28649, doi:10.1029/96JD02722, 1996. 
Ciccioli, P. and Mannozzi, M.: High-Molecular-Weight Carbonyls and Carboxylic Acids, in: Wiley: Volatile Organic Compounds in the Atmosphere, edited by: Koppmann, R., 292-343, Blackwell Publishing Ltd., 2007.

Ciccioli, P., Centritto, M., and Loreto, F.: Biogenic volatile organic compound emissions from vegetation fires, Plant. Cell Environ., 37, 1810-1825, doi:10.1111/pce.12336, 2014.

Colomb, A., Williams, J., Crowley, J., Gros, V., Hofmann, R., Salisbury, G., Klüpfel, T., Kormann, R., Stickler, A., Forster, C., and Lelieveld, J.: Airborne Measurements of Trace Organic Species in the Upper Troposphere Over Europe: the Impact of Deep Convection, Environ. Chem., 3, 244, doi:10.1071/EN06020, 2006.

Crutzen, P. J., Williams, J., Poschl, U., Hoor, P., Fischer, H., Warneke, C., Holzinger, R., Hansel, A., Lindinger, W., Scheeren, B., and Lelieveld, J.: High spatial and temporal resolution measurements of primary organics and their oxidation products over the tropical forests of Surinam, Atmos. Environ., 34, 1161-1165, doi:10.1016/s1352-2310(99)00482-3, 2000.

Davison, B., Brunner, A., Ammann, C., Spirig, C., Jocher, M., and Neftel, A.: Cut-induced VOC emissions from agricultural grasslands, Plant Biol., 10, 76-85, doi:10.1055/s-2007-965043, 2008.

de Gouw, J. and Warneke, C.: Measurements of volatile organic compounds in the earth's atmosphere using proton-transferreaction mass spectrometry, Mass Spectrom. Rev., 26, 223-257, doi:10.1002/mas.20119, 2007.

De Gouw, J. A., Howard, C. J., Custer, T. G., and Fall, R.: Emissions of volatile organic compounds from cut grass and clover are enhanced during the drying process, Geophys. Res. Lett., 26, 811-814, doi:10.1029/1999GL900076, 1999.

De Gouw, J. A., Howard, C. J., Custer, T. G., Baker, B. M., and Fall, R.: Proton-transfer chemical-ionization mass spectrometry allows real-time analysis of volatile organic compounds released from cutting and drying of crops, Environ. Sci. Technol., 34, 2640-2648, doi:10.1021/es991219k, 2000.

de Gouw, J., Warneke, C., Karl, T., Eerdekens, G., van der Veen, C., and Fall, R.: Sensitivity and specificity of atmospheric trace gas detection by proton-transfer-reaction mass spectrometry, Int. J. Mass Spectrom., 223-224, 365-382, doi:10.1016/S13873806(02)00926-0, 2003.

Derstroff, B., Sander, R., Hueser, I., Parchatka, U., Bourtsoukidis, E., Crowley, J. N., Fischer, H., Phillips, G. J., Schuladen, J., Mallik, C., Harder, H., Sauvage, C., Stönner, C., Kesselmeier, J., Lelieveld, J., and Williams, J.: Volatile organic compounds (VOCs) in photochemically aged air the Eastern and Western Mediterranean, Atmos. Chem. Phys. Discuss., in preparation, 2016.

Donoso, L., Romero, R., Rondon, A., Fernandez, E., Oyola, P., and Sanhueza, E.: Natural and anthropogenic $\mathrm{C}_{2}$ to $\mathrm{C}_{6}$ hydrocarbons in the central-eastern Venezuelan atmosphere during the rainy season, J. Atmos. Chem., 25, 201-214, doi:10.1007/BF00053791, 1996.

Fall, R.: Abundant oxygenates in the atmosphere: a biochemical perspective, Chem. Rev., 103, 4941-4952, doi:10.1021/cr0206521, 2003.

Feng, Y., Wen, S., Wang, X., Sheng, G., He, Q., Tang, J., and Fu, J.: Indoor and outdoor carbonyl compounds in the hotel ballrooms in Guangzhou, China, Atmos. Environ., 38, 103-112, doi:10.1016/j.atmosenv.2003.09.061, 2004.
Finlayson-Pitts, B. J. and Pitts, J. N.: Photochemistry of Important Atmospheric Species, in: Chemistry of the Upper and Lower Atmosphere, 86-129, Elsevier, Academic Press, USA, 2000.

Finlayson-Pitts, B. J. and Pitts Jr., J. N.: Tropospheric air pollution: Ozone, airborne toxics, polycyclic aromatic hydrocarbons, and particles, Science, 276, 1045-1052, doi:10.1126/science.276.5315.1045, 1997.

Folkins, I., Chatfield, R., Singh, H., Chen, Y., and Heikes, B.: Ozone production efficiencies of acetone and peroxides in the upper troposphere, Geophys. Res. Lett., 25, 1305-1308, doi:10.1029/98GL01030, 1998.

Genard-Zielinski, A.-C., Boissard, C., Fernandez, C., Kalogridis, C., Lathière, J., Gros, V., Bonnaire, N., and Ormeño, E.: Variability of BVOC emissions from a Mediterranean mixed forest in southern France with a focus on Quercus pubescens, Atmos. Chem. Phys., 15, 431-446, doi:10.5194/acp-15-431-2015, 2015.

Goldstein, A. H. and Schade, G. W.: Quantifying biogenic and anthropogenic contributions to acetone mixing ratios in a rural environment, Atmos. Environ., 34, 4997-5006, doi:10.1016/S13522310(00)00321-6, 2000.

Grant, D. D., Fuentes, J. D., Chan, S., Stockwell, W. R., Wang, D., and Ndiaye, S. A.: Volatile organic compounds at a rural site in western Senegal, J. Atmos. Chem., 60, 19-35, doi:10.1007/s10874-008-9106-1, 2008.

Greenberg, J. P. and Zimmerman, P. R.: Nonmethane hydrocarbons in remote tropical, continental, and marine atmospheres, J. Geophys. Res., 89, 4767, doi:10.1029/JD089iD03p04767, 1984.

Grosjean, D., Grosjean, E., and Moreira, L. F. R.: Speciated Ambient Carbonyls in Rio de Janeiro, Brazil, Environ. Sci. Technol., 36, 1389-1395, doi:10.1021/es0111232, 2002.

Hafner, S. D., Howard, C., Muck, R. E., Franco, R. B., Montes, F., Green, P. G., Mitloehner, F., Trabue, S. L., and Rotz, C. A.: Emission of volatile organic compounds from silage: Compounds, sources, and implications, Atmos. Environ., 77, 827839, doi:10.1016/j.atmosenv.2013.04.076, 2013.

Hellén, H., Hakola, H., Reissell, A., and Ruuskanen, T. M.: Carbonyl compounds in boreal coniferous forest air in Hyytiälä, Southern Finland, Atmos. Chem. Phys., 4, 1771-1780, doi:10.5194/acp-4-1771-2004, 2004.

Hellén, H., Hakola, H., Pystynen, K.-H., Rinne, J., and Haapanala, S.: $\mathrm{C}_{2}-\mathrm{C}_{10}$ hydrocarbon emissions from a boreal wetland and forest floor, Biogeosciences, 3, 167-174, doi:10.5194/bg-3-1672006, 2006.

Ho, K. F., Lee, S. C., Louie, P. K. K., and Zou, S. C.: Seasonal variation of carbonyl compound concentrations in urban area of Hong Kong, Atmos. Environ., 36, 1259-1265, doi:10.1016/S13522310(01)00570-2, 2002.

Holzinger, R., Rottenberger, S., Crutzen, P. J., Kesselmeier, J., and Sandoval-Soto, L.: Emissions of volatile organic compounds from Quercus ilex L. measured by Proton Transfer Reaction Mass Spectrometry under different environmental conditions, J. Geophys. Res., 105, 20573-20579, doi:10.1029/2000jd900296, 2000.

Holzinger, R., Lee, A., Paw, K. T., and Goldstein, U. A. H.: Observations of oxidation products above a forest imply biogenic emissions of very reactive compounds, Atmos. Chem. Phys., 5, 67-75, doi:10.5194/acp-5-67-2005, 2005.

Holzinger, R., Millet, D. B., Williams, B., Lee, A., Kreisberg, N., Hering, S. V., Jimenez, J., Allan, J. D., Worsnop, D. R., and 
Goldstein, A. H.: Emission, oxidation, and secondary organic aerosol formation of volatile organic compounds as observed at Chebogue Point, Nova Scotia, J. Geophys. Res., 112, D10S24, doi:10.1029/2006JD007599, 2007.

IBGE: Estimativas da população residente no Brasil e unidades da Federação com data de referência em $1^{\circ}$ de julho de 2014, available at: ftp://ftp.ibge.gov.br/Estimativas_de Populacao/Estimativas_2014/estimativa_dou_2014.pdf (last access: 1 September 2016), 2014.

Inomata, S., Tanimoto, H., Kato, S., Suthawaree, J., Kanaya, Y., Pochanart, P., Liu, Y., and Wang, Z.: PTR-MS measurements of non-methane volatile organic compounds during an intensive field campaign at the summit of Mount Tai, China, in June 2006, Atmos. Chem. Phys., 10, 7085-7099, doi:10.5194/acp-10-70852010, 2010

Isidorov, V. A., Zenkevich, I. G., and Ioffe, B. V.: Volatile organic compounds in the atmosphere of forests, Atmos. Environ., 19, 1-8, doi:10.1016/0004-6981(85)90131-3, 1985.

Jardine, A. B., Jardine, K. J., Fuentes, J. D., Martin, S. T., Martins, G., Durgante, F., Carneiro, V., Higuchi, N., Manzi, A. O., and Chambers, J. Q.: Highly reactive light-dependent monoterpenes in the Amazon, Geophys. Res. Lett., 42, 1576-1583, doi:10.1002/2014GL062573, 2015.

Jardine, K., Abrell, L., Kurc, S. A., Huxman, T., Ortega, J., and Guenther, A.: Volatile organic compound emissions from Larrea tridentata (creosotebush), Atmos. Chem. Phys., 10, 1219112206, doi:10.5194/acp-10-12191-2010, 2010.

Jenkin, M. E., Saunders, S. M., and Pilling, M. J.: The tropospheric degradation of volatile organic compounds: a protocol for mechanism development, Atmos. Environ., 31, 81-104, doi:10.1016/S1352-2310(96)00105-7, 1997.

Jordan, A., Haidacher, S., Hanel, G., Hartungen, E., Märk, L., Seehauser, H., Schottkowsky, R., Sulzer, P., and Märk, T. D.: A high resolution and high sensitivity proton-transfer-reaction time-offlight mass spectrometer (PTR-TOF-MS), Int. J. Mass. Spectrom., 286, 122-128, doi:10.1016/j.ijms.2009.07.005, 2009a.

Jordan, C., Fitz, E., Hagan, T., Sive, B., Frinak, E., Haase, K., Cottrell, L., Buckley, S., and Talbot, R.: Long-term study of VOCs measured with PTR-MS at a rural site in New Hampshire with urban influences, Atmos. Chem. Phys., 9, 4677-4697, doi:10.5194/acp-9-4677-2009, 2009b.

Kalogridis, C., Gros, V., Sarda-Esteve, R., Langford, B., Loubet, B., Bonsang, B., Bonnaire, N., Nemitz, E., Genard, A.-C., Boissard, C., Fernandez, C., Ormeño, E., Baisnée, D., Reiter, I., and Lathière, J.: Concentrations and fluxes of isoprene and oxygenated VOCs at a French Mediterranean oak forest, Atmos. Chem. Phys., 14, 10085-10102, doi:10.5194/acp-14-10085-2014, 2014.

Karl, T., Crutzen, P. J., Mandl, M., Staudinger, M., Guenther, A., Jordan, A., Fall, R., and Lindinger, W.: Variability-lifetime relationship of VOCs observed at the Sonnblick Observatory 1999 - estimation of HO-densities, Atmos. Environ., 35, 5287-5300, doi:10.1016/S1352-2310(01)00341-7, 2001.

Karl, T., Harren, F., Warneke, C., de Gouw, J., Grayless, C., and Fall, R.: Senescing grass crops as regional sources of reactive volatile organic compounds, J. Geophys. Res.-Atmos., 110, 111, doi:10.1029/2005JD005777, 2005a.

Karl, T., Harley, P., Guenther, A., Rasmussen, R., Baker, B., Jardine, K., and Nemitz, E.: The bi-directional exchange of oxygenated VOCs between a loblolly pine (Pinus taeda) planta- tion and the atmosphere, Atmos. Chem. Phys., 5, 3015-3031, doi:10.5194/acp-5-3015-2005, 2005b.

Karl, T., Guenther, A., Turnipseed, A., Tyndall, G., Artaxo, P., and Martin, S.: Rapid formation of isoprene photo-oxidation products observed in Amazonia, Atmos. Chem. Phys., 9, 7753-7767, doi:10.5194/acp-9-7753-2009, 2009.

Karl, T. G., Spirig, C., Rinne, J., Stroud, C., Prevost, P., Greenberg, J., Fall, R., and Guenther, A.: Virtual disjunct eddy covariance measurements of organic compound fluxes from a subalpine forest using proton transfer reaction mass spectrometry, Atmos. Chem. Phys., 2, 279-291, doi:10.5194/acp-2-279-2002, 2002.

Karl, T. G., Christian, T. J., Yokelson, R. J., Artaxo, P., Hao, W. M., and Guenther, A.: The Tropical Forest and Fire Emissions Experiment: method evaluation of volatile organic compound emissions measured by PTR-MS, FTIR, and GC from tropical biomass burning, Atmos. Chem. Phys., 7, 5883-5897, doi:10.5194/acp-7-5883-2007, 2007.

Katzenstein, A. S., Doezema, L. A., Simpson, I. J., Blake, D. R., and Rowland, F. S.: Extensive regional atmospheric hydrocarbon pollution in the southwestern United States, P. Natl. Acad. Sci. USA, 100, 11975-11979, doi:10.1073/pnas.1635258100, 2003.

Keenan, T., Niinemets, Ü., Sabate, S., Gracia, C., and Peñuelas, J.: Process based inventory of isoprenoid emissions from European forests: model comparisons, current knowledge and uncertainties, Atmos. Chem. Phys., 9, 4053-4076, doi:10.5194/acp-94053-2009, 2009.

Kesselmeier, J. and Staudt, M.: Biogenic volatile organic compounds (VOC): An overview on emission, physiology and ecology, J. Atmos. Chem., 33, 23-88, doi:10.1023/A:1006127516791, 1999.

Kesselmeier, J., Kuhn, U., Rottenberger, S., Biesenthal, T., Wolf, A., Schebeske, G., Andreae, M. O., Ciccioli, P., Brancaleoni, E., Frattoni, M., Oliva, S. T., Botelho, M. L., Silva, C. M. A., and Tavares, T. M.: Concentrations and species composition of atmospheric volatile organic compounds (VOCs) as observed during the wet and dry season in Rondonia (Amazonia), J. Geophys. Res., 107, 1-13, doi:10.1029/2000jd000267, 2002.

Kim, S., Kim, S.-Y., Lee, M., Shim, H., Wolfe, G. M., Guenther, A. B., He, A., Hong, Y., and Han, J.: Impact of isoprene and HONO chemistry on ozone and OVOC formation in a semirural South Korean forest, Atmos. Chem. Phys., 15, 4357-4371, doi:10.5194/acp-15-4357-2015, 2015.

Kirstine, W., Galbally, I., Ye, Y., and Hooper, M.: Emissions of volatile organic compounds (primarily oxygenated species) from pasture, J. Geophys. Res., 103, 10605, doi:10.1029/97JD03753, 1998.

König, G., Brunda, M., Puxbaum, H., Hewitt, C. N., Duckham, S. C., and Rudolph, J.: Relative contribution of oxygenated hydrocarbons to the total biogenic VOC emissions of selected midEuropean agricultural and natural plant species, Atmos. Environ., 29, 861-874, doi:10.1016/1352-2310(95)00026-U, 1995.

Kuhn, U., Ganzeveld, L., Thielmann, A., Dindorf, T., Schebeske, G., Welling, M., Sciare, J., Roberts, G., Meixner, F. X., Kesselmeier, J., Lelieveld, J., Kolle, O., Ciccioli, P., Lloyd, J., Trentmann, J., Artaxo, P., and Andreae, M. O.: Impact of Manaus City on the Amazon Green Ocean atmosphere: ozone production, precursor sensitivity and aerosol load, Atmos. Chem. Phys., 10, 9251-9282, doi:10.5194/acp-10-9251-2010, 2010. 
Kwok, E. S. C., Arey, J., and Atkinson, R.: Alkoxy Radical Isomerization in the $\mathrm{OH}$ Radical-Initiated Reactions of $\mathrm{C}_{4}-\mathrm{C}_{8} n$ Alkanes, J. Phys. Chem., 100, 214-219, doi:10.1021/jp952036x, 1996.

Langford, B., Davison, B., Nemitz, E., and Hewitt, C. N.: Mixing ratios and eddy covariance flux measurements of volatile organic compounds from an urban canopy (Manchester, UK), Atmos. Chem. Phys., 9, 1971-1987, doi:10.5194/acp-9-1971-2009, 2009.

Langford, B., Acton, W., Ammann, C., Valach, A., and Nemitz, E.: Eddy-covariance data with low signal-to-noise ratio: time-lag determination, uncertainties and limit of detection, Atmos. Meas. Tech., 8, 4197-4213, doi:10.5194/amt-8-4197-2015, 2015.

Laothawornkitkul, J., Taylor, J. E., Paul, N. D., and Hewitt, C. N.: Biogenic volatile organic compounds in the Earth system, New Phytol., 183, 27-51, doi:10.1111/j.1469-8137.2009.02859.x, 2009.

Lee, A., Goldstein, A. H., Kroll, J. H., Ng, N. L., Varutbangkul, V., Flagan, R. C., and Seinfeld, J. H.: Gas-phase products and secondary aerosol yields from the photooxidation of 16 different terpenes, J. Geophys. Res., 111, D17305, doi:10.1029/2006JD007050, 2006.

Legreid, G., Lööv, J. B., Staehelin, J., Hueglin, C., Hill, M., Buchmann, B., Prevot, A. S. H., and Reimann, S.: Oxygenated volatile organic compounds (OVOCs) at an urban background site in Zürich (Europe): Seasonal variation and source allocation, Atmos. Environ., 41, 8409-8423, doi:10.1016/j.atmosenv.2007.07.026, 2007.

Lindinger, W., Hansel, A., and Jordan, A.: On-line monitoring of volatile organic compounds at pptv levels by means of protontransfer-reaction mass spectrometry (PTR-MS) medical applications, food control and environmental research, Int. J. Mass Spectrom., 173, 191-241, doi:10.1016/S0168-1176(97)00281-4, 1998.

Liu, Y., Yuan, B., Li, X., Shao, M., Lu, S., Li, Y., Chang, C.C., Wang, Z., Hu, W., Huang, X., He, L., Zeng, L., Hu, M., and Zhu, T.: Impact of pollution controls in Beijing on atmospheric oxygenated volatile organic compounds (OVOCs) during the 2008 Olympic Games: observation and modeling implications, Atmos. Chem. Phys., 15, 3045-3062, doi:10.5194/acp15-3045-2015, 2015.

Liu, Y., Liu, C.-Y., Yang, G.-P., Zhang, H.-H., and Zhang, S.: Biogeochemistry of dimethylsulfoniopropionate, dimethylsulfide and acrylic acid in the Yellow Sea and the Bohai Sea during autumn, Environ. Chem., 13, 127-139, doi:10.1071/EN15025, 2016.

Martin, S. T., Andreae, M. O., Althausen, D., Artaxo, P., Baars, H., Borrmann, S., Chen, Q., Farmer, D. K., Guenther, A., Gunthe, S. S., Jimenez, J. L., Karl, T., Longo, K., Manzi, A., Müller, T., Pauliquevis, T., Petters, M. D., Prenni, A. J., Pöschl, U., Rizzo, L. V., Schneider, J., Smith, J. N., Swietlicki, E., Tota, J., Wang, J., Wiedensohler, A., and Zorn, S. R.: An overview of the Amazonian Aerosol Characterization Experiment 2008 (AMAZE08), Atmos. Chem. Phys., 10, 11415-11438, doi:10.5194/acp10-11415-2010, 2010.

Martinez, R. D., Buitrago, A. A., Howell, N. W., Hearn, C. H., and Joens, J. A.: The near U.V. absorption spectra of several aliphatic aldehydes and ketones at $300 \mathrm{~K}$, Atmos. Environ. A-Gen., 26, 785-792, doi:10.1016/0960-1686(92)90238-G, 1992.
McKeen, S. A., Gierczak, T., Burkholder, J. B., Wennberg, P. O., Hanisco, T. F., Keim, E. R., Gao, R.-S., Liu, S. C., Ravishankara, A. R., and Fahey, D. W.: The photochemistry of acetone in the upper troposphere: A source of odd-hydrogen radicals, Geophys. Res. Lett., 24, 3177-3180, doi:10.1029/97GL03349, 1997.

McKinney, K. A., Lee, B. H., Vasta, A., Pho, T. V., and Munger, J. $\mathrm{W}$.: Emissions of isoprenoids and oxygenated biogenic volatile organic compounds from a New England mixed forest, Atmos. Chem. Phys., 11, 4807-4831, doi:10.5194/acp-11-4807-2011, 2011.

Miller, R. E., Jensen, R., and Woodrow, I. E.: Frequency of cyanogenesis in tropical rainforests of far north Queensland, Australia, Ann. Bot., 97, 1017-1044, doi:10.1093/aob/mcl048, 2006.

Millet, D. B., Baasandorj, M., Farmer, D. K., Thornton, J. A., Baumann, K., Brophy, P., Chaliyakunnel, S., de Gouw, J. A., Graus, M., Hu, L., Koss, A., Lee, B. H., Lopez-Hilfiker, F. D., Neuman, J. A., Paulot, F., Peischl, J., Pollack, I. B., Ryerson, T. B., Warneke, C., Williams, B. J., and Xu, J.: A large and ubiquitous source of atmospheric formic acid, Atmos. Chem. Phys., 15, 6283-6304, doi:10.5194/acp-15-6283-2015, 2015.

Moore, D. P., Remedios, J. J., and Waterfall, A. M.: Global distributions of acetone in the upper troposphere from MIPAS spectra, Atmos. Chem. Phys., 12, 757-768, doi:10.5194/acp-12-7572012, 2012.

National Center for Biotechnology: PubChem Compound Database; $\mathrm{CID}=6569$, Open Chem. database, available at: http://pubchem.ncbi.nlm.nih.gov/compound/2-Butanone, last access: 22 March 2015.

Neier, W. and Strehlke, G.: 2-Butanone, in Ullmann's Encyclopedia of Industrial Chemistry, Wiley-VCH, Weinheim, 2002.

Niinemets, Ü., Fares, S., Harley, P., and Jardine, K. J.: Bidirectional exchange of biogenic volatiles with vegetation: emission sources, reactions, breakdown and deposition., Plant. Cell Environ., 37, 1790-809, doi:10.1111/pce.12322, 2014.

Nobre, C. A., Obregón, G. O., Marengo, J. A., Fu, R., and Poveda, G.: Characteristics of Amazonian climate: Main features, Geophys. Monogr. Ser., 186, 149-162, doi:10.1029/2008GM000720, 2009.

Noe, S. M., Kimmel, V., Hüve, K., Copolovici, L., PortilloEstrada, M., Püttsepp, Ü., Jõgiste, K., Niinemets, Ü., Hörtnagl, L., and Wohlfahrt, G.: Ecosystem-scale biosphereatmosphere interactions of a hemiboreal mixed forest stand at Järvselja, Estonia, Forest Ecol. Manage., 262, 71-81, doi:10.1016/j.foreco.2010.09.013, 2011.

Noe, S. M., Hüve, K., Niinemets, Ü., and Copolovici, L.: Seasonal variation in vertical volatile compounds air concentrations within a remote hemiboreal mixed forest, Atmos. Chem. Phys., 12, 3909-3926, doi:10.5194/acp-12-3909-2012, 2012.

Noe, S. M., Krasnov, D., Krasnova, A., Cordey, H. P. E., and Niinemets, Ü.: Seasonal variation and characterisation of reactive trace gas mixing ratios over a hemi-boreal mixed forest site in Estonia, Boreal Environ. Res., 21, 332-344, 2016.

Nölscher, A. C., Yáñez-Serrano, A. M., Wolff, S., de Araujo, A. C., Lavrič, J. V., Kesselmeier, J., and Williams, J.: Unexpected seasonality in quantity and composition of Amazon rainforest air reactivity, Nat. Commun., 7, 10383, doi:10.1038/ncomms10383, 2016. 
Nozière, B.: Organic reactions increasing the absorption index of atmospheric sulfuric acid aerosols, Geophys. Res. Lett., 32, L03812, doi:10.1029/2004GL021942, 2005.

Pinho, P. G., Pio, C. A., and Jenkin, M. E.: Evaluation of isoprene degradation in the detailed tropospheric chemical mechanism, MCM v3, using environmental chamber data, Atmos. Environ., 39, 1303-1322, doi:10.1016/j.atmosenv.2004.11.014, 2005.

Prather, M. J. and Jacob, D. J.: A persistent imbalance in $\mathrm{HO}_{x}$ and $\mathrm{NO}_{x}$ photochemistry of the upper troposphere driven by deep tropical convection, Geophys. Res. Lett., 24, 3189-3192, doi:10.1029/97GL03027, 1997.

Rinne, H. J. I., Guenther, A. B., Greenberg, J. P., and Harley, P. C.: Isoprene and monoterpene fluxes measured above Amazonian rainforest and their dependence on light and temperature, Atmos. Environ., 36, 2421-2426, doi:10.1016/S1352-2310(01)00523-4, 2002.

Rodigast, M., Mutzel, A., Schindelka, J., and Herrmann, H.: A new source of methylglyoxal in the aqueous phase, Atmos. Chem. Phys., 16, 2689-2702, doi:10.5194/acp-16-2689-2016, 2016.

Rollins, A. W., Kiendler-Scharr, A., Fry, J. L., Brauers, T., Brown, S. S., Dorn, H.-P., Dubé, W. P., Fuchs, H., Mensah, A., Mentel, T. F., Rohrer, F., Tillmann, R., Wegener, R., Wooldridge, P. J., and Cohen, R. C.: Isoprene oxidation by nitrate radical: alkyl nitrate and secondary organic aerosol yields, Atmos. Chem. Phys., 9, 6685-6703, doi:10.5194/acp-9-6685-2009, 2009.

Ruuskanen, T. M., Müller, M., Schnitzhofer, R., Karl, T., Graus, M., Bamberger, I., Hörtnagl, L., Brilli, F., Wohlfahrt, G., and Hansel, A.: Eddy covariance VOC emission and deposition fluxes above grassland using PTR-TOF, Atmos. Chem. Phys., 11, 611-625, doi:10.5194/acp-11-611-2011, 2011.

Sander, R.: Compilation of Henry's law constants (version 4.0) for water as solvent, Atmos. Chem. Phys., 15, 4399-4981, doi:10.5194/acp-15-4399-2015, 2015.

Schade, G. W., Solomon, S. J., Dellwik, E., Pilegaard, K., and Ladstätter-Weissenmayer, A.: Methanol and other VOC fluxes from a Danish beech forest during late springtime, Biogeochemistry, 106, 337-355, doi:10.1007/s10533-010-9515-5, 2011.

Schauer, J. J., Kleeman, M. J., Cass, G. R., and Simoneit, B. R. T.: Measurement of Emissions from Air Pollution Sources. 3. $\mathrm{C}_{1}-$ $\mathrm{C}_{29}$ Organic Compounds from Fireplace Combustion of Wood, Environ. Sci. Technol., 35, 1716-1728, doi:10.1021/es001331e, 2001.

Singh, H. B., Salas, L. J., Chatfield, R. B., Czech, E., Fried, A., Walega, J., Evans, M. J., Field, B. D., Jacob, D. J., Blake, D., Heikes, B., Talbot, R., Sachse, G., Crawford, J. H., Avery, M. A., Sandholm, S., and Fuelberg, H.: Analysis of the atmospheric distribution, sources, and sinks of oxygenated volatile organic chemicals based on measurements over the Pacific during TRACE-P, J. Geophys. Res.-Atmos., 109, D15S07, doi:10.1029/2003JD003883, 2004.

Slowik, J. G., Vlasenko, A., McGuire, M., Evans, G. J., and Abbatt, J. P. D.: Simultaneous factor analysis of organic particle and gas mass spectra: AMS and PTR-MS measurements at an urban site, Atmos. Chem. Phys., 10, 1969-1988, doi:10.5194/acp-10-19692010, 2010.

Sommariva, R., de Gouw, J. A., Trainer, M., Atlas, E., Goldan, P. D., Kuster, W. C., Warneke, C., and Fehsenfeld, F. C.: Emissions and photochemistry of oxygenated VOCs in urban plumes in the Northeastern United States, Atmos. Chem. Phys., 11, 70817096, doi:10.5194/acp-11-7081-2011, 2011.

Song, G. C. and Ryu, C.-M.: Two Volatile Organic Compounds Trigger Plant Self-Defense against a Bacterial Pathogen and a Sucking Insect in Cucumber under Open Field Conditions, Int. J. Mol. Sci., 14, 9803-9819, doi:10.3390/ijms14059803, 2013.

Steeghs, M., Bais, H. P., de Gouw, J., Goldan, P., Kuster, W., Northway, M., Fall, R., and Vivanco, J. M.: Proton-transfer-reaction mass spectrometry as a new tool for real time analysis of rootsecreted volatile organic compounds in Arabidopsis, Plant Physiol., 135, 47-58, doi:10.1104/pp.104.038703, 2004.

Stein, A. F., Draxler, R. R., Rolph, G. D., Stunder, B. J. B., Cohen, M. D., Ngan, F., Stein, A. F., Draxler, R. R., Rolph, G. D. Stunder, B. J. B., Cohen, M. D., and Ngan, F.: NOAA's HYSPLIT Atmospheric Transport and Dispersion Modeling System, B. Am. Meteorol. Soc., 96, 2059-2077, doi:10.1175/BAMS-D14-00110.1, 2015.

Sun, Z., Copolovici, L., and Niinemets, Ü.: Can the capacity for isoprene emission acclimate to environmental modifications during autumn senescence in temperate deciduous tree species Populus tremula?, J. Plant Res., 125, 263-274, doi:10.1007/s10265-0110429-7, 2012.

Verschueren, K.: Methyl Ethyl Ketone, in: Handbook of Environmental Data on Organic Chemicals, 850-852, Van Nostrand Reinhold Co., New York, 1983.

Vetter, J.: Plant cyanogenic glycosides, Toxicon, 38, 11-36, doi:10.1016/S0041-0101(99)00128-2, 2000.

Warneke, C., Karl, T., Judmaier, H., Hansel, A., Jordan, A., Lindinger, W., and Crutzen, P. J.: Acetone, methanol, and other partially oxidized volatile organic emissions from dead plant matter by abiological processes: Significance for atmospheric $\mathrm{HO}_{x}$ chemistry, Global Biogeochem. Cy., 13, 9-17, doi:10.1029/98GB02428, 1999.

Warneke, C., Mckeen, S. A., Gouw, J. A. De, Goldan, P. D., Kuster, W. C., Holloway, J. S., Williams, E. J., Lerner, B. M., Parrish, D. D., Trainer, M., Fehsenfeld, F. C., Kato, S., Atlas, E. L., Baker, A., and Blake, D. R.: Determination of urban volatile organic compound emission ratios and comparison with an emissions database, J. Geophys. Res.-Atmos., 112, D10S47, doi:10.1029/2006JD007930, 2007.

Wheatley, R., Hackett, C., Bruce, A., and Kundzewicz, A.: Effect of substrate composition on production of volatile organic compounds from Trichoderma spp. Inhibitory to wood decay fungi, Int. Biodeter. Biodegr., 39, 199-205, doi:10.1016/S09648305(97)00015-2, 1997.

Wilkins, K.: Volatile metabolites from actinomycetes, Chemosphere, 32, 1427-1434, doi:10.1016/0045-6535(96)00051-3, 1996.

Williams, J., Pöschl, U., Crutzen, P. J., Hansel, A., Holzinger, R., Warneke, C., Lindinger, W., and Lelieveld, J.: An atmospheric chemistry interpretation of mass scans obtained from a proton transfer mass spectrometer flown over the tropical rainforest of Surinam, J. Atmos. Chem., 38, 133-166, doi:10.1023/a:1006322701523, 2001.

Yáñez-Serrano, A. M., Nölscher, A. C., Williams, J., Wolff, S., Alves, E., Martins, G. A., Bourtsoukidis, E., Brito, J., Jardine, K., Artaxo, P., and Kesselmeier, J.: Diel and seasonal changes of biogenic volatile organic compounds within and above an 
Amazonian rainforest, Atmos. Chem. Phys., 15, 3359-3378, doi:10.5194/acp-15-3359-2015, 2015.

Zannoni, N., Gros, V., Lanza, M., Sarda, R., Bonsang, B., Kalogridis, C., Preunkert, S., Legrand, M., Jambert, C., Boissard, C., and Lathiere, J.: $\mathrm{OH}$ reactivity and concentrations of biogenic volatile organic compounds in a Mediterranean forest of downy oak trees, Atmos. Chem. Phys., 16, 1619-1636, doi:10.5194/acp16-1619-2016, 2016.
Zhou, X. and Mopper, K.: Carbonyl compounds in the lower marine troposphere over the Caribbean Sea and Bahamas, J. Geophys. Res., 98, 2385, doi:10.1029/92JC02772, 1993.

Zimmerman, P. R., Greenberg, J. P., and Westberg, C. E.: Measurements of atmospheric hydrocarbons and biogenic emission fluxes in the Amazon Boundary layer, J. Geophys. Res., 93, 1407, doi:10.1029/JD093iD02p01407, 1988. 